This manuscript is contextually identical with the following paper:

doi.org/10.1016/j.apsoil.2018.12.018

Applied Soil Ecology 136 (2019) 106-115

\title{
Green tree retention enhances negative short-term effects of clear-cutting on enchytraeid assemblages in a temperate forest
}

Gergely Boros ${ }^{1,2,3^{*}}$, Bence Kovács ${ }^{1,2,4}$, Péter Ódor ${ }^{1,2}$

${ }^{1}$ MTA Centre for Ecological Research, Institute of Ecology and Botany, Vácrátót, Hungary

${ }^{2}$ MTA Centre for Ecological Research, GINOP Sustainable Ecosystem Research Group, Tihany, Hungary

${ }^{3}$ Szent István University, Department of Zoology and Animal Ecology, Gödöllő, Hungary

${ }^{4}$ Eötvös Loránd University, Department of Plant Systematics, Ecology and Theoretical Biology, Budapest, Hungary

*corresponding author: boros.gergo@okologia.mta.hu

Address: Alkotmány street 2-4, Vácrátót, 2163, Hungary

\begin{abstract}
We studied the response of enchytraeid (Annelida: Oligochaeta) community structure to different forest management treatments via an open-field forestry experiment in a managed sessile oakhornbeam forest in Hungary. The applied forestry treatments were 1) clear-cutting 2) clear
\end{abstract}


cutting with a small patch of retention tree group, 3) gap-cutting, 4) preparation cutting and 5) control (closed mature stand).

Our questions were: how did the selected forestry treatments influence the abundance and species richness of enchytraeids two years after the intervention, and how could the worms compensate the altered environmental conditions by vertical movements in topsoil layers $(0-12 \mathrm{~cm})$. The effects of the treatments on the species composition of the assemblages and species-specific responses were also analysed.

Two years after the treatments, a strong response of enchytraeids was observed in clear-cutting and even more in retention tree group: in both treatments the abundance and the species richness of enchytraeids were reduced. Species did not show vertical movements into deeper layers and were not able to tolerate the altered soil conditions caused by changed microclimate. Gap-cutting and preparation cutting did not differ significantly from control plots. Our study showed that right after the interventions tree retention at the size of one tree height in diameter had no sheltering effect on this important soil decomposer animal community. These results are in contrast with earlier findings in boreal zones, where soil organic layer is considered a well buffered habitat against environmental changes. Oppositely, enchytraeid assemblages in a temperate deciduous forest are more diverse but seem more vulnerable to management-related alterations in soil conditions (soil temperate increment, reduced soil moisture).

Keywords: potworms; soil invertebrates; mesofauna; vertical distribution; shelterwood forestry; forest management 


\section{Introduction}

Compared to natural disturbances, forest management considerably changes the stand structure and tree species composition of the forests both at stand and landscape scales (Bengtsson et al., 2000, Lindenmayer and Franklin, 2002). Management modifies the biodiversity (including species richness, abundance structure, species composition) of many organism groups (Paillet et al., 2010, Chaudhary et al., 2016). It has many direct effects like eliminating important substrates and microhabitats (e.g. dead wood, cavity trees, rare admixing tree species, pits and mounds), that are essential for many organism groups such as bryophytes, lichens, fungi, saproxylic beetles and cavity nesting birds (Müller et al., 2007, Ódor et al., 2013). However, most organism groups are affected by the indirect effects of forest management via altered light, air and soil conditions (Suggitt et al., 2011, Tinya et al., 2009). Forestry can generate significant structural and chemical changes in forest soil (Thiffault et al., 2011, Kishchuk et al., 2014). These processes can alter soil invertebrate assemblages, which in turn influence ecosystem services like organic matter decomposition or nutrient cycling (Thomas and Packham, 2007, Zicsi et al., 2011).

Responses of soil mesofauna to forestry treatments were studied mostly in coniferous forests in boreal and mountainous regions, and were rather contrasting. A rapid increase in the number of soil springtails was observed 2-3 years after clear-cutting in Finland (Huhta, 1976), whereas Čuchta et al. (2012) reported a decline in numbers of edaphic collembolas after 3 years of clearing in the High Tatra National Park, Slovakia. Addison and Barber (1997) observed, that springtails were unaffected by clear-cutting in a mixed forest in Northern Ontario, as well as Siira-Pietikäinen et al. (2001), who did not find changes in the abundance and the community structure of collembolans as a result of forest harvesting. Mite populations responded with sharp decrease after clear-cutting (Huhta et al., 1969, Addison and Barber, 1997, Lindo and Visser, 2004). Lóšková et 
al. (2013) found reduced oribatid abundance in those clearcuts, from which fallen timber had been removed. Tardigrades were more abundant in the deforested areas and seemed to be related to high soil moisture content (Uhía and Briones, 2002). These relationships were scarcely studied in temperate deciduous forests and such mesofauna members as enchytraeids.

Enchytraeid worms (Annelida: Clitellata) are small oligochaetes belonging to the soil mesofauna (Brussaard et al., 2012). Their ecological functions are similar to earthworms but at smaller scale (van Vliet et al., 1993, Didden and Marinissen, 1994). Enchytraeids are decomposers of decaying plant material but also known as microbivoreous and saprophagous organisms (Didden, 1993), hence, play an important role in nutrient cycling (Briones et al., 1998 a,b, Cole et al., 2000, Koutika et al., 2001). Their deposited excrements are microbial activity hotspots, consequently significant in mineralisation (Förster et al., 1995). Mixing of mineral and organic soil particles (van Vliet et al., 1995) indicate the indispensable role of this family of soil-dwelling invertebrates which have been easily considered as ecosystem engineers (Hastings et al., 2007, Pelosi and Römbke, 2016). Soil structure is affected by enchytraeids as their burrowing activity increases the soil porosity (Van Vliet et al., 1993) and through this, oxygen concentration and nutrient leaching potential of water-extractable compounds (Roithmeier and Pieper, 2009). Most of the enchytraeid populations (70-90\%) are living in the uppermost $5-10 \mathrm{~cm}$ of the soil but some species can migrate to deeper layers depending on soil temperature (Dózsa-Farkas, 1992). Due to their high density in soil (Didden, 1993) Enchytraeids are also known as abundant decomposers in many habitats, such as forests.

Their sensitivity to forest management practices is known mainly from boreal forests, where the enchytraeid abundances increased due to forestry treatments (Huhta, 1976, Lundkvist, 1983, SiiraPietikäinen et al., 2001, Malmström et al., 2009). However, all these boreal habitats were very poor 
in enchytraeid species (one to six) and dominated (98-99\%) by only one species, Cognettia sphagnetorum.

In this paper, we studied the effect of different forest management treatments on the community structure (abundance, species richness and species composition) of enchytraeid assemblages via an open-field forestry experiment. We compared forestry treatments that are widely used in temperate deciduous forests and belong to different forestry systems. Cutting areas with small patches of retention tree groups (or solitary retention trees) are common elements of forested landscape managed by clear-cutting (artificial regeneration) or shelterwood (natural regeneration) forestry systems (Matthews, 1991). The buffering effect of retention tree groups in clear-cuttings is widely studied for many organism groups with controversial statements (Rosenvald and Lõhmus, 2008). Within shelterwood forestry system, the first step to the regeneration of forest stands is the preparation cutting (partial harvest) that accelerates natural tree regeneration before final cutting, which was also included in the experiment. In the last decades there was a paradigm shift in forest management from economically sustainable forestry to a more ecologically sustainable, multipurpose forestry, which tries to mimic natural disturbances (Pommerening and Murphy, 2004, Bauhus et al., 2009). An important forestry practice regarding to this continuous cover forestry is the creation of gaps which was also included in this experiment.

In this study, the following questions were raised:

1. How do the selected forestry treatments influence the abundance and the species richness of enchytraeids in the topsoil $(0-12 \mathrm{~cm})$ two years after the intervention?

2. How can the individuals compensate the altered environmental conditions in the topsoil (0-12 $\mathrm{cm})$ by vertical movements?

3. What are the effects of treatments on the species composition of the assemblages, and are there species specific responses on the treatments? 


\section{Materials and methods}

\subsection{Site description and experimental design}

The study site was in the Pilis Mountains $\left(47^{\circ} 40^{\prime} \mathrm{N}, 18^{\circ} 54^{\prime} \mathrm{E}\right)$ which is a north-eastern ridge of the Transdanubian Range, Hungary (Fig. 1A). The plots were situated on north-facing, moderate slopes $\left(7.0-10.6^{\circ}\right)$ at $380-450 \mathrm{~m}$ a.s.l. (Fig. 1B.). Average annual mean temperature is $9.0-9.5^{\circ} \mathrm{C}$ with a mean annual precipitation of 600-650 mm (Dövényi, 2010). The bedrock is limestone and sandstone with loess, the most common soil type is lessivage brown forest soil (luvisol in FAO soil classification), which is acidic ( $\mathrm{pH}$ of the $0-20 \mathrm{~cm}$ layer is $4.6 \pm 0.2$, Kovács et al., 2018). The site was situated in a managed sessile oak-hornbeam forest stand (Natura 2000 code: 91G0, European Commission, 1992). Due to the applied shelterwood system, the stand is even-aged (80 years old), and has relatively uniform structure and species composition. The upper canopy layer is dominated by sessile oak (Quercus petraea (Matt.) Liebl.), while turkey oak (Quercus cerris L.), European beech (Fagus sylvatica L.) and wild cherry (Prunus avium L.) also appeared as subordinate species. Secondary canopy layer was formed by hornbeam (Carpinus betulus L.) and manna ash (Fraxinus

ornus L.) as subordinate species. The shrub layer is scarce. The understory layer is formed by general and mesic forest species, particularly hairy sedge (Carex pilosa Scopoli) and wood melic (Melica uniflora L.).

Four silvicultural treatments were carried out with control in a randomized complete block design, using six blocks as replicates. Treatments were as follows:

1. Control (C): closed-canopy stand without any treatment;

2. Clear-cutting (CC): a circular clear-cut ( $80 \mathrm{~m}$ in diameter, $0.5 \mathrm{ha}$ ), surrounded by closed stand; 
3. Gap-cutting (G): an artificial circular gap in the closed stand (20 $\mathrm{m}$ in diameter, approximately one tree height/diameter ratio, $314 \mathrm{~m}^{2}$ );

4. Preparation cutting $(\mathrm{P})$ : in a circle of $80 \mathrm{~m}$ diameter, $30 \%$ of the basal area of the dominant tree layer was felled spatially uniformly, and the complete secondary tree and shrub layer were also removed;

5. Retention tree group (R) within the clear-cut (CC) treatment: a circular group of retained dominant trees (20 $\mathrm{m}$ in diameter, 8-12 individuals).

The resulting number of plots was 30 (Fig. 1B,C).

Clear-cutting, retention tree group and preparation cutting represent characteristic stages of rotation forestry system, while gap-cutting is often implemented in the framework of continuous cover forestry (selection forestry) system. All experimental forestry treatments were established in December 2014 and January 2015.

The main aim of the general experiment was investigating the effect of these treatments on forest site environmental conditions (microclimate, soil conditions), biodiversity (including many organism groups) and stand regeneration. More information about the research is available on the website of the experiment (MTA Centre for Ecological Research, 2018).

Two years after the implementation (in 2016), considerable changes in the microclimate of the harvested plots were observed (Table 1. and Supplementary Material Table S1., for detailed analysis see Kovács et al., 2018).

\subsection{Data collection}

Data collection followed a Before-After Control-Impact design (Green, 1979): enchytraeid assemblages were surveyed in 2014 before any treatment and continuously after the implementations (in 2015 and 2016) applying the same methodology. Enchytraeids were collected 
twice a year, in May and in September. Three soil samples per plot were taken with a split soil corer (diameter of $5 \mathrm{~cm}$ ) to $12 \mathrm{~cm}$ depth (volume approximately $236 \mathrm{~cm}^{3}$ per sample). In 2015 and 2016 soil cores were vertically divided to three layers $(0-4 \mathrm{~cm}, 4-8 \mathrm{~cm}$ and $8-12 \mathrm{~cm}$, approximately $78 \mathrm{~cm}^{3}$ each in volume) to assess the vertical distribution of enchytraeids. Each sample was put separately in a plastic bag in the field, transferred to the laboratory and stored at $4{ }^{\circ} \mathrm{C}$.

Samples from the same plot and layers were mixed and then a single aliquot with the volume of 78 $\mathrm{cm}^{3}$ was taken for worm extraction by wet funnel method (O’Connor, 1962).

Living enchytraeid individuals were kept in Petri-dishes with tap water, counted under dissecting microscope (Optika SZM-1, $\times 10-\times 20$ ). They were identified in vivo under light microscope (Nikon Eclipse 50i, magnification between $\times 100-\times 400$, mostly $\times 200)$ using Schmelz (2003) and Schmelz and Collado (2010, 2012). Some specimens of each species were stored in $70 \%$ ethanol as a reference collection and deposited in the Institute for Ecology and Botany, MTA Centre for Ecological Research. For each species, the abundance per sample was counted. Density values (individuals per $\mathrm{m}^{2}$ ) were estimated by dividing the number of individuals per subsample by 0.0019625 , which is the surface of the soil cores given in $\mathrm{m}^{2}$. Juvenile specimens were not appropriate for identification, except for Buchholzia appendiculata (Buchholz, 1862), which were included when estimating total abundance.

\subsection{Data analysis}

Effect of the treatments as a fixed factor on the whole abundance and species richness of the topsoil (12 cm depth, $78 \mathrm{~cm}^{3}$ sample) was explored in each year (2014, 2015 and 2016) separately using general linear mixed models (GLMM; Faraway, 2006, Zuur et al., 2009). The reason of the separate analyses of the years is that they are qualitatively different (not simple time replications), 2014 represents before treatment, while 2015 and 2016 after treatment conditions. For abundance 
Gaussian error structure and untransformed data, for species richness Poisson error structure and logarithmic link function were used, in each case blocks were defined as random factor. The treatment effect was analysed by $\mathrm{F}$ statistics for abundance and $\mathrm{Chi}^{2}$ statistics for species richness, likelihood ratio test based coefficient of determination of fixed factor $\left(\mathrm{R}^{2}\right)$ was also calculated (Barton, 2016). Tukey pairwise multiple comparisons of treatment levels were made using 0.05 significance level and general linear hypothesis tests (Hothorn et al., 2008).

Treatment effects on the abundance and species richness of different vertical layers in the surveys of 2015 and 2016 were analysed separately. In this case, treatment (five levels), vertical layers (three levels) and years (two levels) were used as fixed factors and blocks as random factor during the GLMM applying the same assumptions as above. All interaction terms of the fixed factors were included in the first model, which was selected by backward elimination based on log-likelihood ratio statistics (Faraway, 2006). Tukey-type multiple comparisons between treatment levels in each layer and year combination were based on least-squares means (Lenth, 2016). During the modelling, the normality as well as the homogeneity of the residuals were checked (Faraway, 2006).

The species composition of the treatments was explored by non-metric multidimensional scaling (NMDS) using Bray-Curtis distance function and square root transformation of the abundance data (Borcard et al., 2011). Separate analyses were run for each studied year. The separation of the treatments was also tested by permutational multivariate analysis of variance (PERMANOVA) using Bray-Curtis dissimilarity matrices (Andersson, 2001).

Associations of species with treatments in 2016 were evaluated by indicator species analysis (ISA), which is a combination of fidelity and specificity of the species to a certain treatment type (Dufrêne and Legendre, 1997). The indicator values of the species were tested via Monte-Carlo simulation using 1000 permutations, the accepted significance level was lower than 0.05 . 
All analyses were made in R version 3.4.1 (R Core Team, 2017). The GLMM of abundances were made by the "lme" function of "nlme" package (Pinheiro et al., 2017), that of species richness by "glmer" function of "lme4" package (Bates et al., 2015). Likelihood test based coefficient of determination was calculated by "r.squaredGLMM" function of "MuMIn" package (Barton, 2016). Multiple comparisons of linear hypothesis test were made by "glht" function of "multcomp" package (Hothorn et al., 2008) that of least-square means by "lsmeans" function of "lsmeans" package (Lenth, 2016). NMDS were made by "metaMDS" function, PERMANOVA by the "adonis" function of "vegan" package (Oksanen et al., 2017), and ISA by "indval" function of "abdsv" package (Roberts, 2013).

\section{Results}

\subsection{Enchytraeid fauna and abundance}

The total number of collected adult and subadult specimens (possessing sexual organs) was 2165 in 2014, 1431 in 2015 and 1397 in 2016 (Supplementary Material Table S2.). Remaining worms were juveniles which could be identified only to genus level. Their total number was 524 in 2014 , 593 in 2015 and 483 in 2016.

35 enchytraeid species were found belonging to 7 genera during the whole period. The species richness of the whole sample was 35 in 2014, 32 in 2015 and 33 in 2016.32 species occurred in all years, Fridericia alata Nielsen \& Christensen, 1959, and Fridericia conculcata Dózsa-Farkas, 1986 only in 2014, Fridericia regularis Nielsen \& Christensen, 1959 only in 2016. 24 species belonged to the genus Fridericia representing more than $50 \%$ of the total number of matured specimens each year. Both Achaeta and Henlea genera were represented by 3 species (A. danica Nielsen \& Christensen, 1959, A. eiseni Vejdovský, 1878, A. pannnonica Graefe, 1989 and $H$. nasuta (Eisen, 1878), H. perpusilla Friend, 1911, H. similis Nielsen \& Christensen, 1959). 
Enchytronia and Marionina genera were only represented by one species (En. parva Nielsen \& Christensen, 1959 and M. communis Nielsen \& Christensen, 1959 respectively).

The abundance distribution of the species was skewed (Supplementary material Fig. S1). The number of common species (relative abundance higher than 5\%) was 5 in 2014, and 7 both in 2015 and 2016. The number of rare species (relative abundance lower than 1\%) decreased during the investigation, it was 18 in 2014, 12 in 2015 and 10 in 2016. Most prevalent species was $B$. appendiculata with a relative abundance of 12-20\% (Supplementary material Fig. S1). Second dominant species was $F$. connata Bretscher, 1902 with 11-15\% relative abundance. The frequency of other species varied with years and treatments. The relative abundance of Henlea nasuta, $\mathrm{H}$. perpusilla and H. similis considerably increased between 2014 and 2016. Adversely, Fridericia bisetosa (Levinsen, 1884) and F. bulboides Nielsen \& Christensen, 1959 decreased exceedingly in 2015 and disappeared completely in all treatments in 2016.

\subsection{Treatment effects}

\subsubsection{Abundance and species richness}

Before the establishment of the experiment, the enchytraeid abundance at the plots differed only marginally (the abundance was slightly higher in later clear-cut plots), while the species richness of the treatments was similar (Tab. 2, Fig. 2). After the establishment of the experimental harvests, the treatments had significant effects both on abundance and species richness. These effects were higher in 2016 than in 2015 (Tab. 2). The values of both variables were lower in clear-cutting and retention tree group treatment than in other treatments, in 2016 these values were even lower in retention tree group than in clear-cutting (Fig. 2).

\subsubsection{Vertical distribution}


Analysis of the effects of treatments, vertical layers and years had similar results for enchytraeid abundance and species richness (Tab. 3). In both cases, treatments and vertical layers had strong significant effects, while the effect of years was not significant. The only difference between them was that in the case of the abundance model the interaction terms were significant, while in species richness model they were not (except the treatment-year interaction). For both variables the values of clear-cutting and retention tree group were significantly lower than in other treatments in the 0 $4 \mathrm{~cm}$ and 4-8 cm layers. In 8-12 cm layer only retention tree group treatment resulted significantly lower values (Fig. 3). It means that retention tree group treatment provided the most unfavourable conditions for enchytraeids, but clear-cutting had also a negative effect on the upper $8 \mathrm{~cm}$ of the soil. In these treatments all specimens disappeared from the upper soil layer and were also not recorded in deeper horizons since there was no accumulation of individuals in the lower layers. There were only few species found in retention tree group treatment: Enchytraeus buchholzi Vejdovský, 1879 in 0-4 cm layer, F. connata and Fridericia rendsinata Dózsa-Farkas, 1972 in 4$8 \mathrm{~cm}$ layer and $A$. pannonica in 8-12 $\mathrm{cm}$ layer. In the clear-cutting the following species could endure: B. appendiculata in 0-4 cm layer, B. appendiculata, E. buchholzi, F. connata and H. nasuta in 4-8 cm layer and A. pannonica, E. buchholzi, F. connata, F. maculatiformis, F. sylvatica Healy, 1979 and $H$. nasuta in 8-12 cm layer.

\subsubsection{Assemblage composition}

In 2014, prior to plot management, species composition at all plots regardless of the planned treatment on them was not significantly different based on PERMANOVA and on NMDS (Fig. 4). In the post-treatment period (in 2015 and 2016), the effects of the treatments were significant, and they were slightly stronger in 2015 than in 2016 (F value of PERMANOVA was 6.28 and 
4.89 , respectively). In 2015, the plots of control, preparation-cutting and gap-cutting had homogenous and separated groups, while the plots of retention tree group and clear-cutting were more heterogeneous but also separated (Fig. 4). In 2016 retention tree group was faunistically separated from other treatments. Control, gap-cutting and preparation cutting treatments created similar homogenous groups than in 2015, while clear-cutting intermingled with gap-cutting (Fig. 4).

According to the ISA, mainly control, gap-cutting and preparation cutting treatments were marked with associated species, the number was relatively higher in 2015 than in 2016 (Table 4). The same species were found in the control plots in the same two years (Enchytraeus bulbosus, En. parva, F. bisetosa and $F$. isseli Rota, 1994), which were extended by $F$. paroniana Issel, 1904 and $F$. waldenstroemi Rota \& Healy, 1999 in 2015. F. dura (Eisen, 1879) and H. perpusilla were related to gap-cutting in both years, in 2015 they were complemented with F. perrieri (Vejdovský, 1878), F. ratzeli (Eisen, 1872) and F. sylvatica, while in 2016 B. appendiculata also preferred gap-cutting. In each year three species associated to preparation-cutting: A. eiseni in both years, while $A$. danica and F. benti Schmelz, 2002 in 2015 and F. nemoralis Nurminen, 1970 and F. hegemon (Vejdovský, 1878) in 2016. With the exception of F. maculatiformis Dózsa-Farkas, 1972 in 2015, no other species associated with clear-cutting and retention tree group treatments characterized by the lowest abundance and species richness of enchytraeids.

\section{Discussion}

Our results revealed that enchytraeids were sensitive to different forestry practices, especially to clear-cutting and retention tree group treatment. All measured variables (abundance, species richness and assemblage composition) decreased in these treatments. These changes are most likely to be explained by alteration of abiotic soil properties caused by these management practices. 
The most drastic effect was observed in retention tree group where the soil moisture was the lowest. Here the drainage effect of the remaining trees along with the sun and wind arriving from the clearcut can considerably desiccate the soil. The lower enchytraeid abundance in this treatment can be mainly explained by the mortality of the individuals since enchytraeids have low dispersion abilities. This explains why this invertebrate group is sensitive to any habitat alternation and responds immediately to changes. The results of their vertical distribution support this finding since worms did not migrate into deeper layer of soil but they disappeared. Coincidently, in a Spanish pine forest (Pinus pinaster Aiton), with the exception of $C$. sphagnetorum, the remaining enchytraeid species did not show vertical migration to overcome adverse environmental conditions and, as a consequence of this, they were unable to tolerate the altered microclimate (Uhía and Briones, 2002). Although, some studies described soil as a relatively buffered environment (Setälä et al., 2000, Siira-Pietikäinen et al., 2001), our results suggest that in temperate zone forests this ascertainment can be true only for deeper soil layers.

In clear-cutting, a reduced abundance of worms was also found. However, the soil of clear-cutting areas can be significantly moister due to the lack of the trees, and because the forest understory responds to this management type with a strong enlargement of tree biomass and species richness (Collins et al., 1985, Jenkins and Parker, 2000) which can buffer the drying effect. Studies in boreal forests showed that the abundance of enchytraeids increased after a few years of clear-cutting (Huhta, 1976, Lundkvist, 1983, Siira-Pietikäinen et al., 2001, Malmström et al., 2009). This can be explained not only by the high amount of resources (i.e. felling residues, dying plant shoots and roots), but also by the increased radiation in clearings that lead to higher soil temperature. This can be advantageous in boreal forests where the average soil temperature is low. In contrast, Uhía and Briones (2002) recorded the minimum numbers of the dominant species C. sphagnetorum in late summer when temperature values were still high but the moisture content was low. Similarly, in 
our experiment the high soil temperature and the drying force of the air which have a documented negative effect on the survival rate of enchytraeids (Springett, 1967, Springett et al., 1970, Abrahamsen, 1971, Briones et al., 1997) could prevail in clear-cutting in the first few years. The lack of leaf litter as a food source deficit indicator can also be a reason for low abundance in clearcutting.

In temperate forests, gaps have the highest soil moisture as a result of the increased throughfall, the lack of tree transpiration and the shading effect of the surrounding stand (Gálhidy et al., 2006, Muscolo et al., 2014, Kovács et al., 2018). This could be a reason of the increased abundance of Henlea species, especially H. perpusilla (Table 4) which is considered as species often found in wet habitats (Schmelz and Collado, 2010). There were no significant differences according to control neither in abundance nor in species richness in preparation cutting, where dispersed arrangement of retained trees has a buffering effect on the forest site conditions and understory (Halpern et al., 2005, 2012, Zenner et al., 2012).

Earlier studies were mainly carried out in coniferous forests, where enchytraeids were dominated by only one species C. sphagnetorum (Nurminen, 1967, Lundkvist, 1983, Siira-Pietikäinen et al., 2001, Uhía and Briones, 2002, Malmström et al., 2009). This species - now considered a complex of species, see Martinsson et al. (2015) - had been classified as stress-tolerant species with asexual reproduction (fragmentation) (Graefe and Schmelz, 1999). Fragmentation is considered as a strategy in response to the environmental changes (Römbke, 1992, Pilipiuk, 1997, 2000), and is positively related to temperature (Standen, 1973). Fragmentation is also reported for $B$. appendiculata that was classified as an r-strategist species (Graefe and Schmelz, 1999) which could explain the dominance of this species in our clear-cut plots. However, enchytraeid assemblages in forest soils in the Pilis Mountains were much more complex without any single predominant species. Most of the species found are able to reproduce only sexually, thus, can be more sensible 
to environmental changes. This might be a reason of decreasing number of rare species during the investigation.

\section{Conclusions}

Our results suggest that unlike reported earlier in previous studies (e.g. ), the abundance and species richness of enchytraeids are negatively affected both by clear-cutting and retention tree group treatments. Such conclusion further supports the coordinated findings of two recent global metaanalyses (Mori and Kitagawa, 2014; Fedrowitz et al., 2014) which revealed that retention forestry in the temperate regions has a limited applicability as a tool of biodiversity conservation. Consequently, "lifeboating" capability determined by Gustafsson et al. (2010), as one of the most important functions of retention tree groups for soil macrofauna, is depending on the taxa, the spatial arrangement (dispersed vs. aggregated) and the extent of the retention groups (SiiraPietikäinen and Haimi, 2009).

Based on our findings, the size of retained tree groups seems crucial, low buffering efficiency of such practice if the diameter of the remaining tree group does not exceed stand average height. Controversial short-term changes (i.e. 2-3 years) among boreal and temperate woodland habitats raise the question of the reliability of longer term predictions in temperate zone, albeit the response of enchytraeids may provide a good approximation for the trend of mesofauna. Long-term investigations (i.e. 10-12 years) in boreal forests found that the enchytraeid population had returned to the pre-treatment level of density (Huhta, 1976, Siira-Pietikäinen and Haimi, 2009). Based on our results it is difficult to predict their long-term response to environmental changes in temperate deciduous forests, since enchytraeid communities are much more heterogeneous here and seem more vulnerable. Therefore, continuing the systematic survey of this organism group is 
crucial both for the more detailed exploration of their response to forestry and the more reliable projections of their community changes and the linked biogeochemical processes.

Moreover, in agreement with Uhía and Briones (2002) we can conclude that solely soil moisture and temperature are probably not sufficient to explain enchytraeid responses to environmental stress, therefore, further studies - long-term effects on the same site or involving other forests types - would be necessary to get a better understanding of the biological reactions to forest managements and their main drivers.

\section{Acknowledgements}

The study was supported by Hungarian Research Fund (OTKA 111887) and by the National Research Development and Innovation Office (GINOP-2.3.2-15-2016-00019). Authors thank the help of László Somay, Zoltán Elek and other members of Forest Ecology Research Group of MTA Centre for Ecological Research during the fieldworks. 


\section{References}

Abrahamsen, G., 1971. The influence of temperature and soil moisture on the population density of Cognettia sphagnetorum (Oligochaeta: Enchytraeidae) in cultures with homogenized raw humus. Pedobiol. 11, 417-424.

Addison, J.A., Barber, K.N. 1997. Response of soil invertebrates to clear-cutting and partial cutting in a boreal mixedwood forest in Northern Ontario. Natural Resources Canada, Canadian Forest Service, Great Lakes Forestry Centre, Sault Ste. Marie, Ont. Info. Rep. GLC-X-1, 23 pp.

Anderson, M.J. 2001. A new method for non-parametric multivariate analysis of variance. Austral Ecol., 26, 32-46.

Barton, K., 2016. MuMIn: Multi-Model Inference. R package version 1.15. https://cran.rproject.org/web/packages/MuMIn/MuMIn.pdf (accessed 21.06.2017)

Bates, D., Maechler, M., Bolker, B., Walker, S., 2015. Fitting linear mixed-effects models using lme4. J. Stat. Softw., 67, 1-48.

Bauhus, J., Puettmann, K., Messier, C., 2009. Silviculture for old-growth attributes. For. Ecol. Manag. 258, 525-537.

Bengtsson, J., Nilsson, S.G., Franc, A., Menozzi, P., 2000. Biodiversity, disturbances, ecosystem function and management of European forests. For. Ecol. Manag. 132, 39-50.

Borcard, D., Gillet, F., Legendre, P., 2011. Numerical Ecology with R. Springer, New York.

Briones, M.J.I., Ineson, P., Piearce, P.G., 1997. Effects of climate change on soil fauna; responses of enchytraeids, Diptera larvae and tardigrades in a transplant experiment. Appl. Soil Ecol. 6, 117-134.

Briones, M.J.I., Carrera, J., Ineson, P., 1998a. Cognettia sphagnetorum (Enchytraeidae) and nutrient cycling in organic soils: a microcosm study. Appl. Soil Ecol. 9, 289-294. 
Briones, M.J.I., Ineson, P., Poskitt, J., 1998b. Climate change and Cognettia sphagnetorum: effects on carbon dynamics and in organic soils. Funct. Ecol. 12, 528-535.

Brussaard, L., Aanen, D.K., Briones, M.J.I., Decaëns, T., De Deyn, G.B., Fayle, T.M., James, S.W., Nobre, T., 2012. Biogeography and phylogenetic community structure of soil invertebrate ecosystem engineers: global to local patterns, implications for ecosystem functioning and services and global environmental change impacts. In: Wall, D.H., Bardgett, R.D., BehanPelletier, V., Herrick, J.E., Jones, T.H., Ritz, K., Six, J., Strong, D.R., van der Putten, W.H. (Eds.), Soil Ecology and Ecosystem Services. Oxford University Press, Oxford, pp. 271-274.

Chaudhary, A., Burivalova, Z., Koh, L.P., Hellweg, S., 2016. Impact of forest management on species richness: global meta-analysis and economic trade-offs. Scientific Reports 6. 23954.

Cole, L., Bardgett, R.D., Ineson, P., 2000. Enchytraeid worms (Oligochaeta) enhance mineralization of carbon in organic upland soils. Eur. J. Soil Sci. 51, 185-192.

Collins, B.S., Dunne, K.P., Pickett, S.T.A., 1985. Responses of forest herbs to canopy gaps, In: Pickett, S.T.A., White, P.S. (Eds.), The Ecology of Natural Disturbance and Patch Dynamics. Academic Press Inc., London, pp. 218-234.

Čuchta, P., Miklisová, D., Kováč, L., 2012. A three-year study of soil Collembola communities in spruce forest stands of the High Tatra Mts. (Slovakia) after a catastrophic windthrow event. Eur. J. Soil Biol. 50, 151-158.

Didden, W.A.M., 1993. Ecology of terrestrial Enchytraeidae. Pedobiol. 37, 2-29.

Didden, W.A.M., Marinissen, J.C.Y., 1994. Effects of oligochaete worms on soil aggregates and implications for organic matter dynamics. In: Transactions $15^{\text {th }}$ World Congress on Soil Science, vol. 4a. Commission III, Acapulco, Mexico, pp. 92-101. 
Dózsa-Farkas, K., 1992. Über die vertikale Verbreitung der Enchytraeiden (Oligochaeta: Enchytraeidae) in einem Hainbuchen-Eichenwald Ungarns. Opusc. Zool. Budapest, 25, 6174.

Dövényi, Z. (Ed.) 2010. Magyarország kistájainak katasztere. MTA Földrajztudományi Kutatóintézet, Budapest.

Dufrêne, M., Legendre, P., 1997. Species assemblages and indicator species: The need for a flexible asymmetrical approach. Ecol. Monogr. 67: 345-366.

European Commission, 1992. Council Directive 92/43/EEC of 21 May 1992 on the conservation of natural habitats and of wild fauna and flora.

Faraway, J.J., 2006. Extending the linear model with R. Chapman and Hall, London.

Fedrowitz, K., Koricheva, J., Baker, S.C., Lindenmayer, D.B., Palik, B., Rosenvald, R., Beese, W., Franklin, J.F., Kouki, J., Macdonald, E., Messier, C., Sverdrup-Thygeson, A.,

Gustafsson, L. 2014. Can retention forestry help conserve biodiversity? A meta-analysis. J. Appl. Ecol. 51, 1669-1679.

Förster, B., Römbke, J., Knacker, T., Morgan, E., 1995. Microcosm study of the interactions between microorganisms and enchytraeid worms in grassland soil and litter. Eur. J. Soil Biol. $31,21-27$.

Gálhidy, L., Mihók, B., Hagyó, A., Rajkai, K., 2006. Effects of gap size and associated changes in light and soil moisture on the understorey vegetation of a Hungarian beech forest. Plant Ecol. $183,133-145$.

Graefe, U., Schmelz, R.M., 1999. Indicator values, strategy types and life forms of terrestrial Enchytraeidae and other microannelids. Newsletter on Enchytraeidae 6, 59-67.

Green, R.H., 1979. Sampling Design and Statistical Methods for Environmental Biologists. J. Wiley, New York. 
Gustafsson, L., Kouki, J., Sverdrup-Thygeson, A. 2010. Tree retention as a conservation measure in clear-cut forests of northern Europe: a review of ecological consequences. Scand. J. Forest Res., 25, 295-308.

Halpern, C.B., Halaj, J., Evans, S.A., Dovciak, M., 2012. Level and pattern of overstory retention interact to shape long-term responses of understories to timber harvest. Ecol. Appl. 22, 20492064.

Halpern, C.B., McKenzie, D., Evans, S.A., Maguire, D.A., 2005. Initial responses of forest understories to varying levels and patterns of green-tree retention. Ecol. Appl. 15, 175-195.

Hastings, A., Byers, J.E., Crooks, J.A., Cuddington, K., Jones, C.G., Lambrinos, J.G., Talley, T.S., Wilson, W.G., 2007. Ecosystem engineering in space and time. Ecol. Lett. 10, 153-164.

Hothorn, T., Bretz, F., Westfall, P., 2008. Simultaneous inference in general parametric models. Biometrical J. 50, 346-363.

Huhta, V. 1976. Effects of clear-cutting on numbers, biomass and community respiration of soil invertebrates. Ann. Zool. Fenn. 13, 63-80.

Huhta. V., Nurminen. M., Valpas. A. 1969. Further notes on the effect of silvicultural practices upon the fauna of coniferous forest soil. Ann. Zool. Fenn. 6, 327-334.

Jenkins, M.A., Parker, G.R., 2000. The response of herbaceous-layer vegetation to anthropogenic disturbance in intermittent stream bottomland forests of southern Indiana, USA. Plant Ecology 151, 223-237.

Kishchuk, B.E., Quideau, S., Wang, Y., Prescott, C., 2014. Long-term soil response to variableretention harvesting in the EMEND (Ecosystem Management Emulating Natural Disturbance) experiment, northwestern Alberta. Can. J. Soil Sci. 94, 263-279.

Koutika, L.S., Didden, V.A.M., Marinissen, J.C.Y., 2001. Soil organic matter distribution as influenced by enchytraeid and earthworm activity. Biol. Fert. Soil. 33, 294-300. 
Kovács, B., Tinya, F., Guba, E., Németh, Cs., Sass, V., Bidló, A., Ódor, P., 2018. The short-term effects of experimental forestry treatments on site conditions in an oak-hornbeam forest. Forests 9: 406

Lenth, R.V., 2016. Least-squares means: the r package lsmeans. J. Stat. Softw. 69(1), 1-33. Lindenmayer, D.B., Franklin, J.F., 2002. Conserving forest biodiversity. A comprehensive multiscaled approach. Island Press, Washington.

Lindo, Z., Visser, S., 2004. Forest floor microarthropod abundance and oribatid mite (Acari: Oribatida) composition following partial and clear-cut harvesting in the mixedwood boreal forest. Can. J. Soil Sci. 34, 998-1006.

Lóšková, J. L’uptáčik, P., Miklisová, D., Kováč, L., 2013. Community structure of soil Oribatida (Acari) two years after windthrow in the High Tatra Mountains Biologia 68/5: 932—940 Section Zoology.

Lundkvist, H. 1983. Effects of clear-cutting on the enchytraeids in a scots pine forest soil in Central Sweden. J. Appl. Ecol. 20, 873-885.

Malmström, A., Persson, T., Ahlström, K., Gongalsky, K.B., Bengtsson, J., 2009. Dynamics of soil meso- and macrofauna during a 5-year period after clear-cut burning in a boreal forest. Appl. Soil Ecol. 43, 61-4.

Martinsson, S., Rota, E., Erséus, C., 2015. Revision of Cognettia (Clitellata, Enchytraeidae): reestablishment of Chamaedrilus and description of cryptic species in the sphagnetorum complex. Syst. Biodivers. 13, 257-277.

Matthews, J.D., 1991. Silvicultural systems. Oxford University Press, Oxford. Mori, A.S., Kitagawa, R., 2014. Retention forestry as a major paradigm for safeguarding forest biodiversity in productive landscapes: A global meta-analysis. Biol. Conserv. 175, 65-7. 
MTA Centre for Ecological Research, 2018. Effect of forestry treatments on forest site, regeneration and biodiversity. An experimental study. https://www.piliskiserlet.okologia.mta.hu/en (accessed 02.10.2018)

Muscolo, A., Bagnato, S., Sidari, M., Mercurio, R., 2014. A review of the roles of forest canopy gaps. J. Forest Res. 25, 725-736.

Müller, J., Hothorn, T., Pretzsch, H., 2007. Long-term effects of logging intensity on structures, birds, saproxylic beetles and wood-inhabiting fungi in stands of European beech Fagus sylvatica L. For. Ecol. Manag. 242, 297-305.

Nurminen, M., 1967. Ecology of enchytraeids (Oligochaeta) in Finnish coniferous forest soil. Ann. Zool. Fenn. 4, 147-157.

O’Connor, F.B., 1962. The extraction of Enchytraeidae from soil, in: Murphy, P.W. (Ed.), Progress in Soil Zoology. Butterworths, London, pp. 279-285.

Ódor, P., Király, I., Tinya, F., Bortignon, F., Nascimbene, J., 2013. Patterns and drivers of species composition of epiphytic bryophytes and lichens in managed temperate forests. For. Ecol. Manag. 306, 256-265.

Oksanen, J., Blanchet, F.G., Friendly, M., Kindt, R., Legendre, P., McGlinn, D., Minchin, P.R., O'Hara, R.B., Simpson, G.L., Solymos, P., Henry, M., Stevens, H., Szoecs, E., Wagner, H., 2017. vegan: Community Ecology Package. R package version 2.4-2. https://cran.rproject.org/web/packages/vegan/vegan.pdf (accessed 17.06.2017)

Paillet, Y., Berges, L., Hjältén, J., Ódor, P., Avon, C., Bernhardt-Römermann, M., Bijlsma, R-J., De Bruyn, L., Fuhr, M., Grandin, U., Kanka, R., Lundin, L., Luque, S., Magura, T., Matesanz, S., Mészáros, I., Sebastià, M-T., Schmidt, W., Standovár, T., Tóthmérész, B., Uotila, A., Valladares, F., Vellak, K., Virtanen, R., 2010. Biodiversity differences between 
managed and unmanaged forests: meta-analysis of species richness in Europe. Conserv.

Biol. 24, 101-112.

Pelosi, C., Römbke, J., 2016. Are Enchytraeidae (Oligochaeta, Annelida) good indicators of agricultural management practices? Soil Biol. Biochem. 100, 255-263.

Pilipiuk, I., 1997. Potworms communities (Enchytraeidae, Oligochaeta) in different types of forest in Puszcza Kampinoska. Fragmenta Faunistica 40, 1-13.

Pilipiuk, I., 2000. Diversification on enchytraeid communities (Enchytraeid, Oligochaeta) of the South Basin of the Biebrza National Park. Fragmenta Faunistica 43, 15-27.

Pinheiro, J., Bates, D., DebRoy, S., Sarkar, D., R Core Team, 2017. nlme: Linear and Nonlinear Mixed Effects Models. R package version 3.1-131. https://cran.rproject.org/web/packages/nlme/nlme.pdf (accessed 17.05.2017)

Pommerening, A., Murphy, S.T., 2004. A review of the history, definitions and methods of continuous cover forestry with special attention to afforestation and restocking. Forestry 77 , $27-44$.

R Core Team, 2017. R: A language and environment for statistical computing. R Foundation for Statistical Computing, Vienna, Austria. https://www.R-project.org/.

Roberts, D.V., 2013. labdsv: Ordination and multivariate analysis for ecology. R package version: 1.6-1. https://cran.r-project.org/web/packages/labdsv/

Roithmeier, O., Pieper, S., 2009. Influence of Enchytraeidae (Enchytraeus albidus) and compaction on nutrient mobilization in an urban soil. Pedobiol. 53, 29-40.

Rosenvald, R., Lõhmus, A., 2008. For what, when, and where is green-tree retention better than clear-cutting? A review of the biodiversity aspects. Forest Ecol. Manag. 255, 1-15.

Römbke, J., 1992. Contribution to the biogeography of some species of terrestrial Enchytraeidae (Oligochaeta; Annelida). Soil Biol. Biochem. 24, 1283-1290. 
Schmelz, R.M., 2003. Taxonomy of Fridericia (Oligochaeta, Enchytraeidae). Revision of species with morphological and biochemical methods. Abhandlungen des Naturwissenschaftlichen Vereins in Hamburg NF 38, Hamburg.

Schmelz, R.M., Collado, R., 2010. A guide to European terrestrial and freshwater species of Enchytraeidae (Oligochaeta). Soil Org. 82, 1-176.

Schmelz, R.M., Rut Collado, R. 2012. Guide to European Terrestrial and Freshwater Species of Enchytraeidae (Oligochaeta): First supplement. Newsletter on Enchytraeidae 12, 53-66.

Setälä, H., Haimi, J., Siira-Pietikäinen, A., 2000. Sensitivity of soil processes in northern forest soils: are management practices a threat? Forest Ecol. Manag. 133, 5-11.

Siira-Pietikäinen, A., Pietikäinen, J., Fritze, H., Haimi, J., 2001. Short-term responses of soil decomposer communities to forest management: clear felling versus alternative forest harvesting methods. Can. J. Forest Res. 31, 88-99.

Siira-Pietikäinen, A., Haimi, J., 2009. Changes in soil fauna 10 years after forest harvestings:

Comparison between clear felling and green-tree retention methods. Forest Ecol. Manag. $258,332-338$.

Springett, J.A., 1967. An ecological study of moorland Enchytraeidae. Ph.D., Durham University $85 \mathrm{pp}$.

Springett, J.A., Brittain, J.E., Springett, B.P., 1970. Vertical movement of Enchytraeidae (Oligochaeta) in moorland soils. Oikos 21, 16-21.

Standen, V., 1973. The production and respiration of an enchytraeid population in a blanket bog. J. Anim. Ecol. 42, 219-245.

Suggitt, A.J., Gillingham, K.P., Hill, J.K., Huntley, B., Kunin, W.E., Roy, D.B., Thomas, C.D., 2011. Habitat microclimates drive fine-scale variation in extreme temperatures. Oikos 120, $1-8$. 
Thiffault, E., Hannam, K.D., Paré, D., Titus, B.D., Hazlett, P.W., Maynard, D.G., Brais, S., 2011. Effects of forest biomass harvesting on soil productivity in boreal and temperate forests - A review. Environ. Rev. 19, 278-309.

Thomas, P.A., Packham, J.R., 2007. Ecology of woodlands and forests. Cambridge University Press, Cambridge.

Tinya, F., Márialigeti, S., Király, I., Németh, B., Ódor, P., 2009. The effect of light conditions on herbs, bryophytes and seedlings of temperate mixed forests in Örség, Western Hungary. Plant Ecol. 204, 69-81.

Uhía, E., Briones, M.J.I. 2002. Population dynamics and vertical distribution of enchytraeids and tardigrades in response to deforestation. Acta Oecol. 23, 349-359.

van Vliet, P.C.J., Beare, M.H., Coleman, D.C., 1995. Population dynamics and functional roles of Enchytraeidae (Oligochaeta) in hardwood forest and agricultural ecosystems. Plant Soil 170, 199-207.

van Vliet, P.C.J., West, L.T., Hendrix, P.F., Coleman, D.C., 1993. The influence of Enchytraeidae (Oligochaeta) on the soil porosity of small microcosms. Geoderma 56, 287-299.

Zenner, E.K., Martin, M.A., Palik, B.J., Peck, J.E., Blinn, C.R., 2012. Response of herbaceous plant community diversity and composition to overstorey harvest within riparian management zones in Northern Hardwoods. Forestry 86, 111-117.

Zicsi, A., Szlavecz, K., Csuzdi, C., 2011. Leaf litter acceptance and cast deposition by peregrine and endemic European lumbricids (Oligochaeta: Lumbricidae). Pedobiol. 54, 145-152.

Zuur, A.F., Ieno, E.N., Walker, N.J., Saveliev, A.A., Smith, G., 2009. Mixed effects models and extension in ecology with R. Springer, New York. 
Figure captions

Figure 1. (A) Map of the study area in the Pilis Mountains, Hungary; (B) Aerial photo of a block (CViktor Tóth); (C) Experimental design of the study: six replicates as blocks and five treatments within each block.

Figure 2. Boxplot of abundance (individuals per $\mathrm{m}^{2}$ ) and species richness of enchytraeids in the treatments (X axis categories) and years (panels). Dots are the medians, boxes are interquartile ranges and whiskers are ranges without outliers. Abbreviation of the treatments are $\mathrm{C}-$ control, CC - clear-cutting, G - gap-cutting, $\mathrm{P}$ - preparation-cutting, and $\mathrm{R}$ - retention tree group. Significant differences based on multiple comparisons in different treatments within a year are marked by letters. Regarding to species richness, there was no significant treatment effect in 2014.

Figure 3. Boxplot of abundance (individuals per $\mathrm{m}^{2}$ ) and species richness of enchytraeids in years (panels), soil layers (subpanels) and treatments (x-axis categories). Dots are the medians, boxes are interquartile ranges and whiskers are ranges without outliers. Abbreviation of the treatments are C - control, CC - clear-cutting, $\mathrm{G}$ - gap-cutting, $\mathrm{P}$ - preparation-cutting, and $\mathrm{R}$ - retention tree group. Significant differences based on multiple comparisons in different treatments within a year and a vertical layer are marked by letters.

Figure 4. Non-metric multidimensional scaling ordination of the plots of different treatments based on the abundance of enchytraeids in different years. The plots are coloured by treatments: control - green, clear-cutting - red, gap-cutting - blue, preparation cutting - purple, retention tree group - 
light brown. The compositional difference between treatments expressed as the results of the PERMANOVA ( $\mathrm{R}^{2}$ - coefficient of determination, $\mathrm{F}$ and $\mathrm{p}$ values $)$ are portrayed on each panels. 
Table 1. Changes of microclimate variables in the treatments two years after the implementation of the experiment (2016). For all variables, the values represent the mean within-block-differences from the control for the whole growing season (March-November). Measurement units: Photosynthetically active radiation $\left(\mu \mathrm{mol} \mathrm{m} \mathrm{m}^{-2}\right)$; Relative diffuse light compared to open conditions $(\%)$; Air temperature $\left({ }^{\circ} \mathrm{C}\right)$; Relative humidity $(\%)$; Vapor pressure deficit $(\mathrm{hPa})$ based on the variables air temperature and relative humidity indicating the drying capacity of the air; Soil temperature $\left({ }^{\circ} \mathrm{C}\right)$ at $1.5 \mathrm{~cm}$ below ground; Soil water content $\left(\mathrm{m}^{3} / \mathrm{m}^{3}\right)$ measured at $10 \mathrm{~cm}$ below soil surface. The letters indicate the significant differences between treatment levels at $\mathrm{p}<0.05$.

\begin{tabular}{|l|cccc|}
\hline Variable & Clear-cutting & Gap-cutting & $\begin{array}{c}\text { Preparation } \\
\text { cutting }\end{array}$ & $\begin{array}{c}\text { Retention tree } \\
\text { group }\end{array}$ \\
\hline Photosynthetically & $665.7^{\mathrm{a}}$ & $234.2^{\mathrm{b}}$ & $131.7^{\mathrm{c}}$ & $128.3^{\mathrm{c}}$ \\
active radiation & $( \pm 339.4)$ & $( \pm 160.2)$ & $( \pm 85.4)$ & $( \pm 74.8)$ \\
Relative diffuse light & $78.5^{\mathrm{a}}$ & $32.4^{\mathrm{b}}$ & $17.7^{\mathrm{c}}$ & $14.3^{\mathrm{c}}$ \\
& $( \pm 6.4)$ & $( \pm 6.4)$ & $( \pm 4.6)$ & $( \pm 9.2)$ \\
Air temperature & $0.39^{\mathrm{a}}$ & $0.17^{\mathrm{bc}}$ & $0.11^{\mathrm{b}}$ & $0.27^{\mathrm{ac}}$ \\
& $( \pm 0.41)$ & $( \pm 0.26)$ & $( \pm 0.18)$ & $( \pm 0.24)$ \\
Relative humidity & $-1.76^{\mathrm{a}}$ & $0.06^{\mathrm{b}}$ & $-0.27^{\mathrm{b}}$ & $-1.93^{\mathrm{a}}$ \\
Vapor pressure deficit & $( \pm 2.82)$ & $( \pm 2.42)$ & $( \pm 1.82)$ & $( \pm 1.78)$ \\
& $0.609^{\mathrm{a}}$ & $0.109^{\mathrm{b}}$ & $0.114^{\mathrm{b}}$ & $0.478^{\mathrm{a}}$ \\
Soil temperature & $( \pm 0.643)$ & $( \pm 0.567)$ & $( \pm 0.376)$ & $( \pm 0.453)$ \\
& $1.29^{\mathrm{a}}$ & $0.47^{\mathrm{b}}$ & $0.83^{\mathrm{bc}}$ & $1.10^{\mathrm{ac}}$ \\
Soil water content & $( \pm 1.25)$ & $( \pm 0.88)$ & $( \pm 0.60)$ & $( \pm 0.76)$ \\
& $0.047^{\mathrm{a}}$ & $0.089^{\mathrm{b}}$ & $0.009^{\mathrm{c}}$ & $-0.016^{\mathrm{c}}$ \\
& $( \pm 0.062)$ & $( \pm 0.077)$ & $( \pm 0.068)$ & $( \pm 0.043)$ \\
\hline
\end{tabular}


Table 2. Treatment effect in general linear mixed models of abundance and species richness of enchytraeid assemblages. Treatment effect on abundance and species richness of enchytraeid assemblages derived from general linear mixed models. Gaussian error structure (F statistics) and Poisson error structure ( $\mathrm{Chi}^{2}$ statistics) were used for abundance and species richness respectively. Degrees of freedom were 4 for treatments and 20 for error. p: significance level; $\mathrm{R}^{2}$ : likelihood-ratio test-based coefficient of determination of the models.

\begin{tabular}{lllll}
\hline Variable & Year & $\mathrm{F} / \mathrm{Chi}^{2}(\mathrm{df}: 4 ; 20)$ & $\mathrm{p}$ & $\mathrm{R}^{2}$ \\
\hline Abundance & 2014 & 3.00 & 0.043 & 0.29 \\
Abundance & 2015 & 16.70 & $<0.001$ & 0.76 \\
Abundance & 2016 & 50.17 & $<0.001$ & 0.87 \\
Species richness & 2014 & 2.97 & 0.563 & 0.10 \\
Species richness & 2015 & 20.85 & $<0.001$ & 0.44 \\
Species richness & 2016 & 60.38 & $<0.001$ & 0.77 \\
\hline
\end{tabular}


Table 3. Statistics of generalized linear mixed models for abundance (Gaussian error structure, F statistics) and species richness (Poisson error structure, $\mathrm{Chi}^{2}$ statistics). Fixed factors were treatment (five levels), vertical layer (three levels) and year (two levels: 2015 and 2016). For abundance all interaction terms were included, likelihood-ratio test-based $\mathrm{R}^{2}$ of the fixed terms was 0.68. The Treatment:Layer interaction was only included in the final model of species richness, likelihood-ratio test-based $\mathrm{R}^{2}$ of the fixed terms was 0.62 .

\begin{tabular}{lrrr}
\hline Variable & \multicolumn{3}{c}{ Abundance } \\
\hline Treatment & 52.88 & 4 & $<0.001$ \\
Layer & 35.61 & 2 & $<0.001$ \\
Year & 2.21 & 1 & 0.139 \\
Treatment:Layer & 2.52 & 8 & 0.014 \\
Treatment:Year & 2.70 & 4 & 0.033 \\
Layer:Year & 9.70 & 2 & 0.001 \\
Treatment:Layer:Year & 2.92 & 8 & 0.005 \\
\hline \multicolumn{4}{c}{ Species richness } \\
\hline \multicolumn{4}{c}{ df } \\
\hline Treatment & Chi ${ }^{2}$ & \multicolumn{3}{c}{4} & $<0.001$ \\
Layer & 104.52 & 2 & $<0.001$ \\
Year & 67.53 & 2 & 0.880 \\
Treatment:Layer & 0.02 & 1 & 0.078 \\
Treatment:Year & 13.77 & 8 & $<0.001$ \\
Layer:Year & 18.24 & 4 & 0.449 \\
Treatment:Layer:Year & 1.60 & 2 & 0.737 \\
\hline
\end{tabular}


Table 4. Indicator species analysis of enchytraeid species related to the treatments in 2015 and 2016. Only species significantly related to a treatment are listed (Monte Carlo simulation, $\mathrm{p}<0.05$, 1000 permutations). Numbers represent the mean abundance (mean individual $\mathrm{m}^{-2}$ ) in different treatments: $\mathrm{C}$ - control, $\mathrm{CC}$ - clear-cutting, $\mathrm{G}$ - gap-cutting, $\mathrm{P}$ - preparation cutting, $\mathrm{R}$ - retention tree group. Treat.: treatments with the highest indicator values. Indval: indicator value related to the treatment, p: significance of the indicator value.

\begin{tabular}{|c|c|c|c|c|c|c|c|c|}
\hline Species & $\mathrm{C}$ & $\mathrm{CC}$ & $\mathrm{G}$ & $\mathrm{P}$ & $\mathrm{R}$ & Treat. & Indval & $\mathrm{p}$ \\
\hline \multicolumn{9}{|l|}{2015} \\
\hline Enchytraeus bulbosus & 3.33 & 0.00 & 0.00 & 0.50 & 0.00 & $\mathrm{C}$ & 0.72 & 0.002 \\
\hline Enchytronia parva & 6.83 & 0.00 & 0.83 & 4.67 & 0.33 & $\mathrm{C}$ & 0.54 & 0.003 \\
\hline F. bisetosa & 5.00 & 0.33 & 0.00 & 0.17 & 0.83 & $\mathrm{C}$ & 0.79 & 0.001 \\
\hline F. bulboides & 3.00 & 0.17 & 0.00 & 0.00 & 0.00 & $\mathrm{C}$ & 0.63 & 0.007 \\
\hline F. isseli & 1.17 & 0.17 & 0.33 & 0.00 & 0.00 & $\mathrm{C}$ & 0.58 & 0.005 \\
\hline F. paroniana & 6.00 & 0.50 & 0.17 & 0.00 & 0.00 & $\mathrm{C}$ & 0.90 & 0.001 \\
\hline F. waldenstroemi & 2.50 & 0.00 & 1.17 & 0.00 & 0.50 & $\mathrm{C}$ & 0.50 & 0.008 \\
\hline F. maculatiformis & 0.67 & 2.83 & 0.33 & 1.17 & 0.33 & $\mathrm{CC}$ & 0.65 & 0.001 \\
\hline F. dura & 0.17 & 0.17 & 1.67 & 0.00 & 0.67 & $\mathrm{G}$ & 0.52 & 0.004 \\
\hline F. perrieri & 0.33 & 0.00 & 4.17 & 0.67 & 0.00 & $\mathrm{G}$ & 0.81 & 0.001 \\
\hline F. ratzeli & 0.00 & 0.00 & 0.83 & 0.00 & 0.00 & $\mathrm{G}$ & 0.50 & 0.022 \\
\hline F. sylvatica & 1.84 & 5.50 & 6.50 & 2.67 & 2.17 & $\mathrm{G}$ & 0.35 & 0.044 \\
\hline Henlea perpusilla & 0.00 & 0.00 & 2.83 & 1.33 & 0.33 & $\mathrm{G}$ & 0.63 & 0.004 \\
\hline Achaeta danica & 1.33 & 0.83 & 0.33 & 5.83 & 0.67 & $\mathrm{P}$ & 0.65 & 0.003 \\
\hline A. eiseni & 2.67 & 1.33 & 1.33 & 5.17 & 0.00 & $\mathrm{P}$ & 0.49 & 0.003 \\
\hline F. benti & 0.00 & 0.00 & 0.00 & 2.50 & 0.83 & $\mathrm{P}$ & 0.62 & 0.003 \\
\hline \multicolumn{9}{|l|}{2016} \\
\hline E. bulbosus & 2.00 & 0.00 & 0.00 & 0.00 & 0.00 & $\mathrm{C}$ & 0.67 & 0.006 \\
\hline En. parva & 5.83 & 1.00 & 0.00 & 4.50 & 0.33 & $\mathrm{C}$ & 0.42 & 0.019 \\
\hline F. bisetosa & 1.33 & 0.00 & 0.00 & 0.00 & 0.00 & $\mathrm{C}$ & 0.67 & 0.002 \\
\hline F. bulboides & 2.00 & 0.00 & 0.00 & 0.00 & 0.00 & $\mathrm{C}$ & 0.50 & 0.038 \\
\hline F. isseli & 3.00 & 0.67 & 0.33 & 0.67 & 0 & $\mathrm{C}$ & 0.54 & 0.015 \\
\hline Buchholzia appendiculata & 11.17 & 6.67 & 14.67 & 3.00 & 0.00 & $\mathrm{G}$ & 0.41 & 0.008 \\
\hline F. dura & 1.00 & 0.17 & 1.83 & 0.50 & 0.00 & $\mathrm{G}$ & 0.44 & 0.027 \\
\hline H. perpusilla & 0.00 & 1.17 & 8.33 & 1.67 & 0.00 & $\mathrm{G}$ & 0.62 & 0.003 \\
\hline A. eiseni & 0.83 & 0.17 & 0.50 & 3.67 & 0.67 & $\mathrm{P}$ & 0.52 & 0.011 \\
\hline F. nemoralis & 3.33 & 3.33 & 1.50 & 5.83 & 0.33 & $\mathrm{P}$ & 0.41 & 0.017 \\
\hline
\end{tabular}




\begin{tabular}{lllllllll} 
F. hegemon & 0.17 & 0.00 & 0.17 & 1.17 & 0.00 & $\mathrm{P}$ & 0.39 & 0.028 \\
\hline
\end{tabular}


Figure 1.

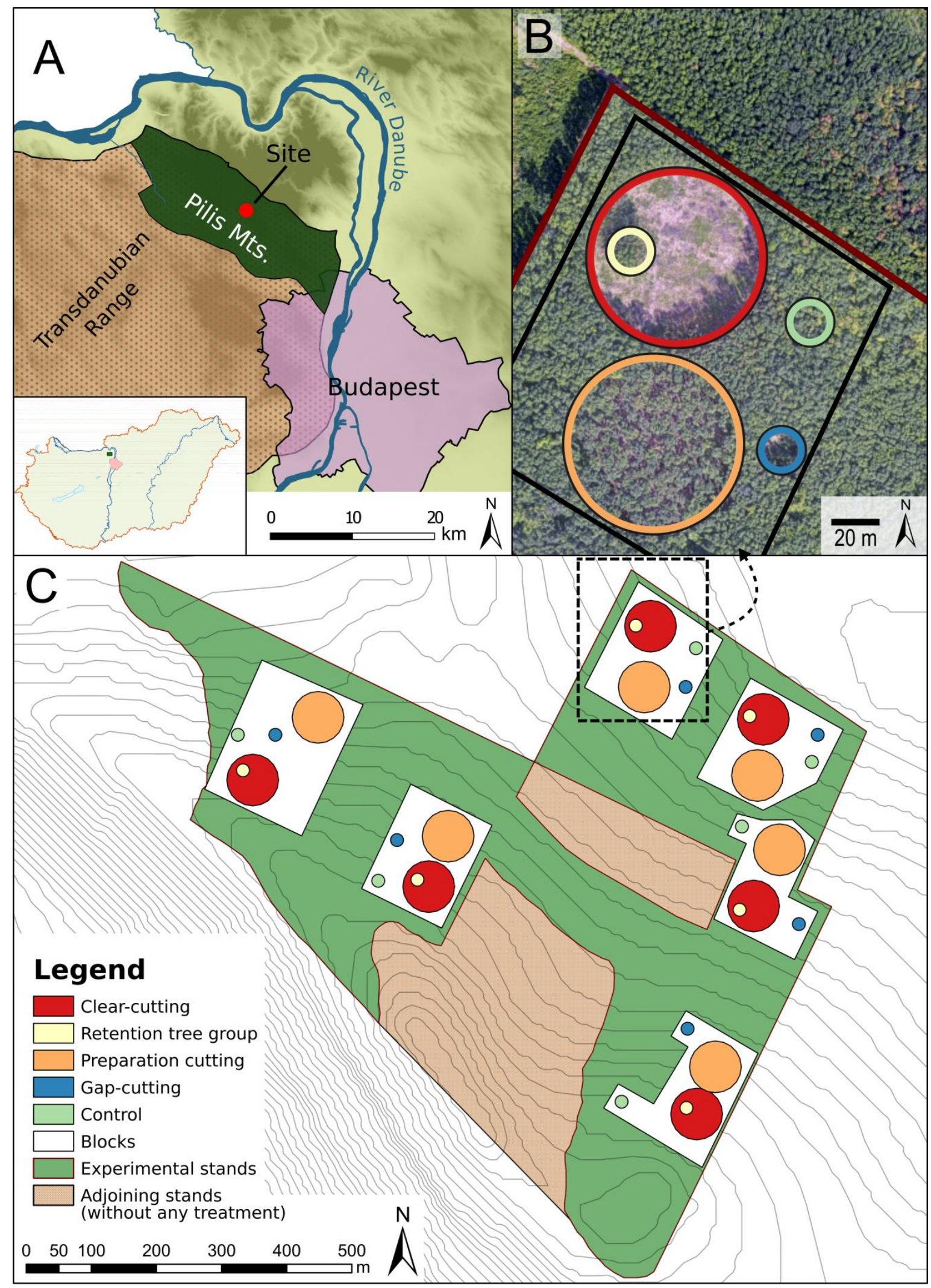


Figure 2.
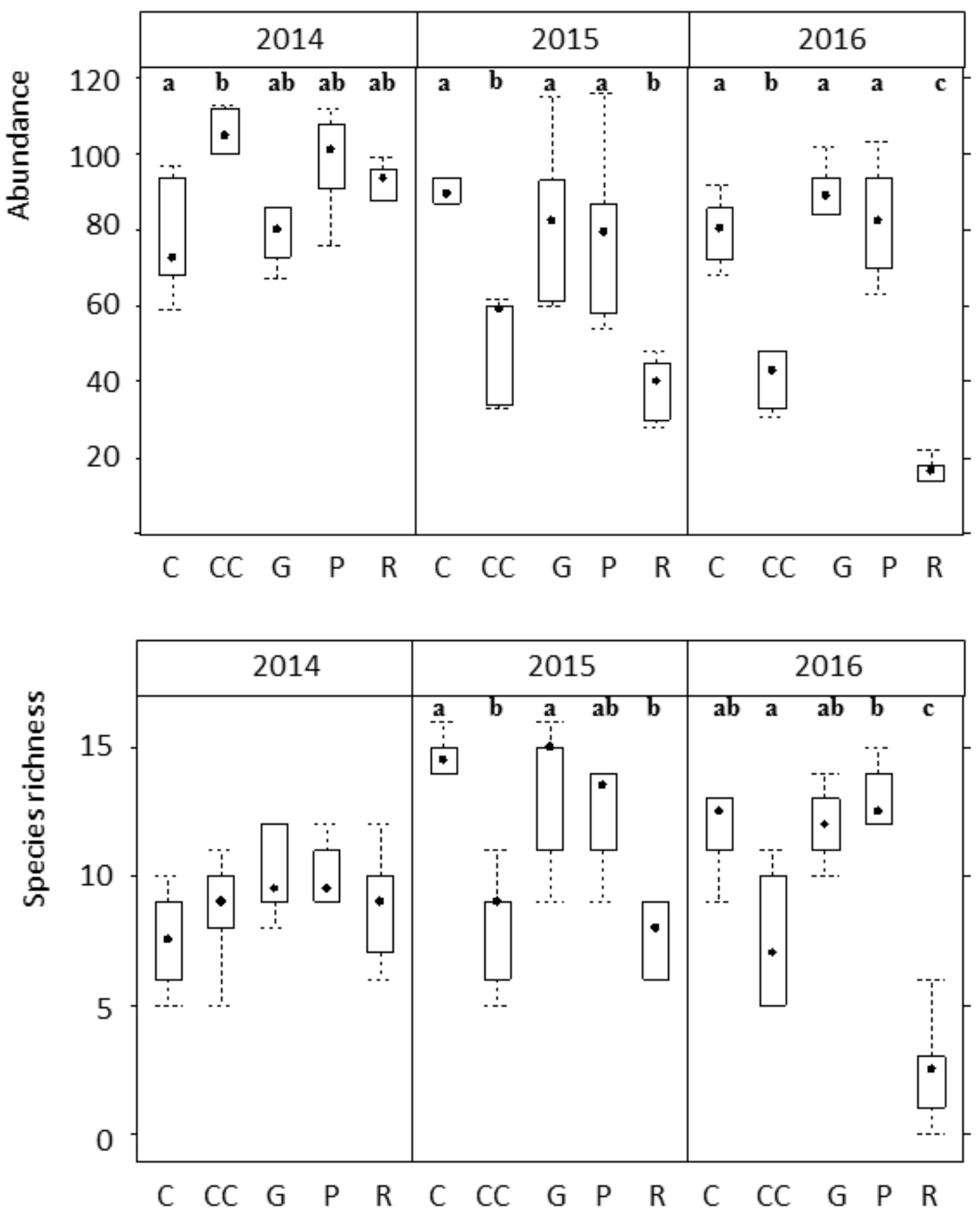
Figure 3.
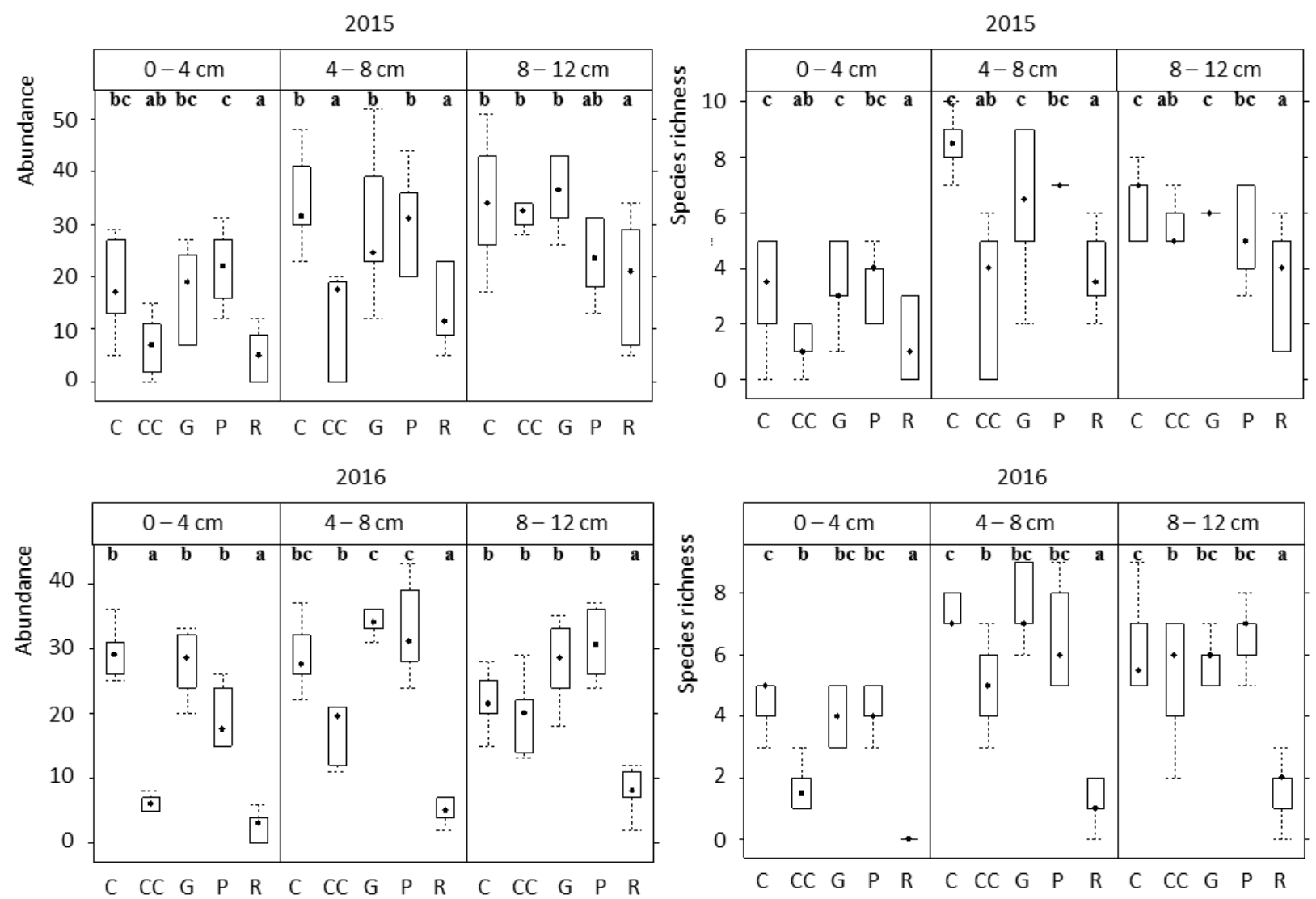
Figure 4.
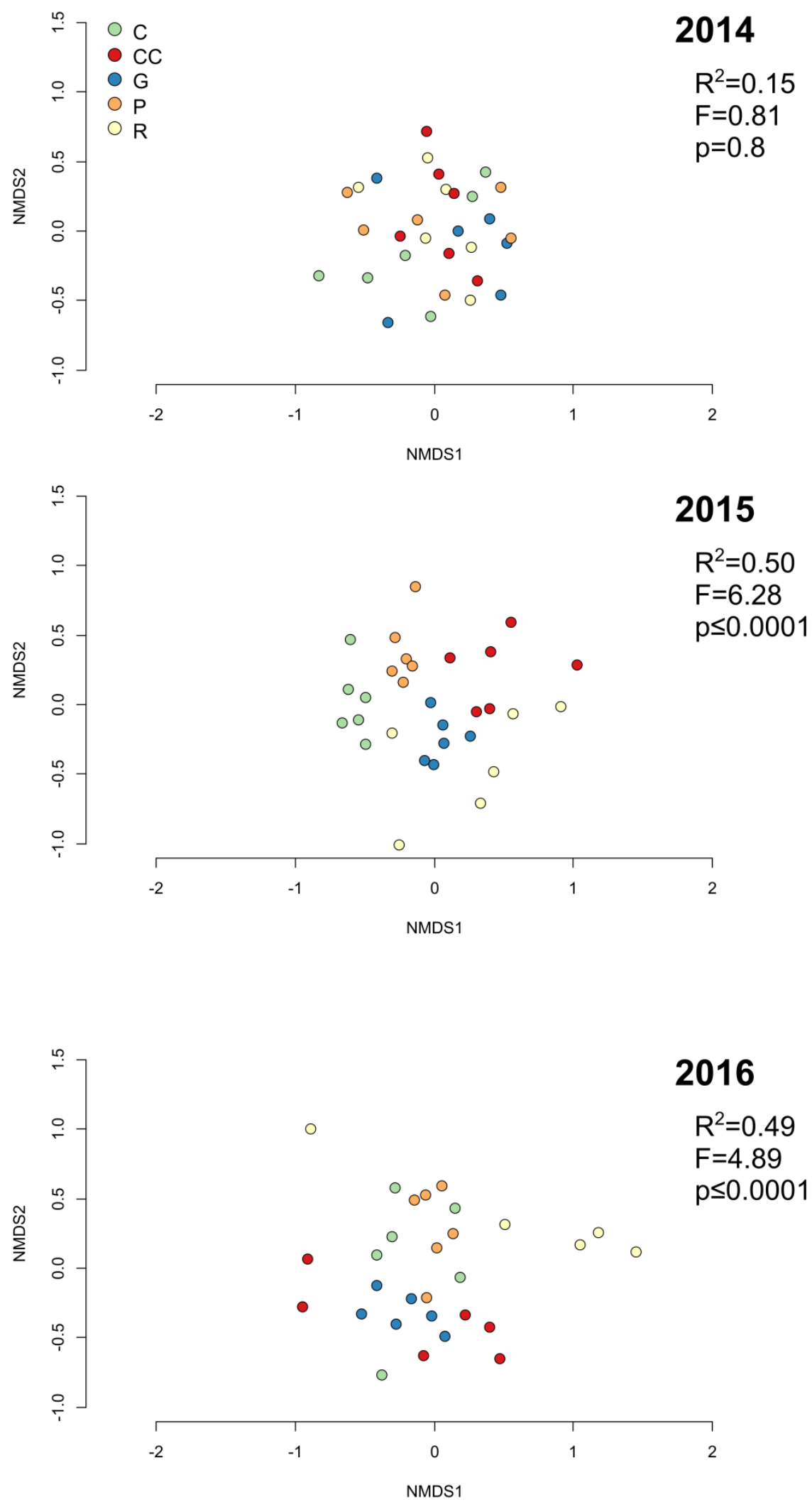


\section{Supplementary material}

Table S1. Mean and standard deviations of the microclimate variables in Pilis Mountains, Hungary based on pooled 24-hour datasets collected in the growing season of 2016. Abbreviations of the variables: PAR: photosynthetically active radiation $\left(\mu \mathrm{mol} \mathrm{m} \mathrm{m}^{-2} \mathrm{~s}^{-1}\right)$; DIFN: relative diffuse light compared to open conditions (\%); Tair: air temperature $\left({ }^{\circ} \mathrm{C}\right)$; RH: relative humidity $(\%)$; VPD: vapor pressure deficit $(\mathrm{kPa})$ based on the variables Tair and RH indicating the drying capacity of the air; Tsoil: soil temperature $\left({ }^{\circ} \mathrm{C}\right)$ at $1.5 \mathrm{~cm}$ below ground; SWC: soil water content $\left(\mathrm{m}^{3} / \mathrm{m}^{3}\right)$ measured at $10 \mathrm{~cm}$ below soil surface. In the case of PAR, daytime (6:00-18:00 UTC) means were calculated due to reasonability.

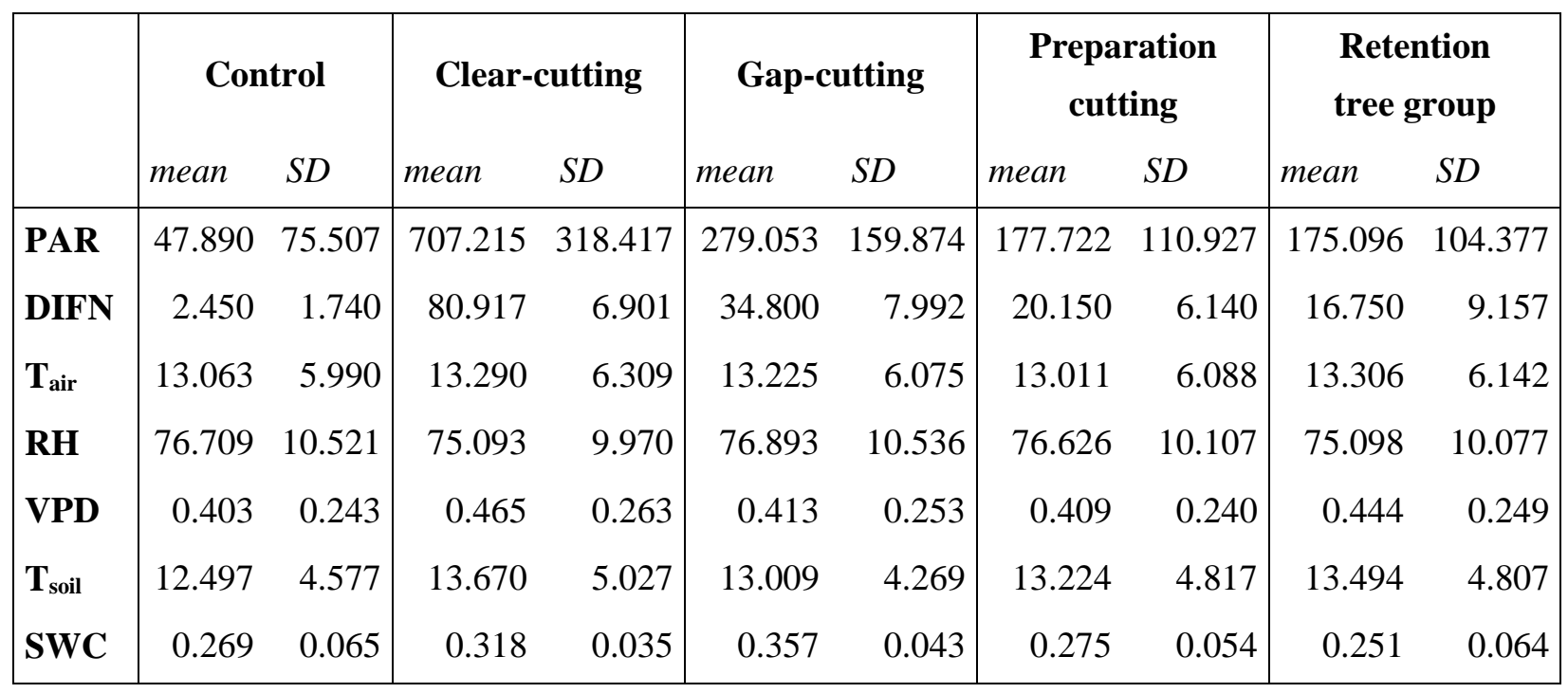


Table S2. List of species and their mean numbers with SD values found in the different treatments (Ccontrol, CC - clear-cutting, $\mathrm{G}$ - gap-cutting, $\mathrm{P}$ - preparation-cutting, and $\mathrm{R}$ - retention tree group) in each year. Juvenile worms could only be identified only at genus level due to missing sexual organs. These specimens were excluded from species richness and species composition analysis, but they were reckoned in total abundance.

\begin{tabular}{|c|c|c|c|c|c|c|c|}
\hline & \multirow{2}{*}{ Species } & \multirow{2}{*}{ Abbreviation } & \multicolumn{5}{|c|}{2014} \\
\hline & & & C & CC & G & $P$ & $\mathrm{R}$ \\
\hline Achaeta danica & Nielsen \& Christensen, 1959 & A_dan & $6 \pm 2.4$ & $7 \pm 2.9$ & $37 \pm 6.1$ & $18 \pm 3.5$ & $11 \pm 3.3$ \\
\hline A. eiseni & Vejdovský, 1878 & A_eis & 0 & $21 \pm 4.2$ & $35 \pm 5.2$ & $7 \pm 2.9$ & 0 \\
\hline A. pannonica & Graefe, 1989 & A_pan & 0 & $16 \pm 4.2$ & $2 \pm 0.8$ & $13 \pm 2.4$ & 0 \\
\hline $\begin{array}{l}\text { Buchholzia } \\
\text { appendiculata }\end{array}$ & (Buchholz, 1862) & B_app & $80 \pm 16.4$ & $133 \pm 11.7$ & $45 \pm 8.4$ & $74 \pm 14.3$ & $95 \pm 18.7$ \\
\hline $\begin{array}{l}\text { Enchytraeus } \\
\text { buchholzi s.l. }\end{array}$ & Vejdovský, 1879 & E_buh & $56 \pm 8.8$ & $72 \pm 6.2$ & $40 \pm 7.8$ & $62 \pm 15.5$ & $66 \pm 12.5$ \\
\hline E. bulbosus & Nielsen \& Christensen, 1963 & E_bul & $7 \pm 2.9$ & 0 & $5 \pm 2.0$ & $27 \pm 5.1$ & $6 \pm 2.4$ \\
\hline Enchytronia parva & Nielsen \& Christensen, 1959 & $E n \_p a$ & $18 \pm 3.5$ & $10 \pm 4.1$ & $17 \pm 3.4$ & $13 \pm 3.7$ & $11 \pm 2.9$ \\
\hline Fridericia alata & Nielsen \& Christensen, 1959 & F_ala & $1 \pm 0.4$ & 0 & 0 & $1 \pm 0.4$ & 0 \\
\hline F. cf. aurita & Issel, 1905 & F_aur & $2 \pm 0.8$ & 0 & 0 & $4 \pm 1.6$ & $1 \pm 0.4$ \\
\hline F. benti & Schmelz, 2002 & F_ben & $6 \pm 2.4$ & 0 & $2 \pm 0.8$ & 0 & 0 \\
\hline F. bisetosa & (Levinsen, 1884) & F_bis & $19 \pm 4.0$ & $13 \pm 3.5$ & $25 \pm 5.1$ & $3 \pm 1.2$ & $12 \pm 3.1$ \\
\hline F. bulboides & Nielsen \& Christensen, 1959 & F_bul & 0 & $11 \pm 4.5$ & $26 \pm 5.3$ & $9 \pm 2.3$ & $31 \pm 5.7$ \\
\hline F. cf. conculcata & Dózsa-Farkas, 1986 & $F_{-}$cul & 0 & 0 & $1 \pm 0.4$ & 0 & 0 \\
\hline F. connata & Bretscher, 1902 & F_con & $69 \pm 9.6$ & $60 \pm 7.0$ & $47 \pm 5.8$ & $76 \pm 7.7$ & $76 \pm 6.7$ \\
\hline F. dura & (Eisen, 1879) & F_dur & $16 \pm 3.3$ & $12 \pm 3.2$ & $8 \pm 2.8$ & $19 \pm 3.5$ & $12 \pm 3.6$ \\
\hline F. galba & (Hoffmeister, 1843) & F_gal & $24 \pm 5.1$ & $24 \pm 3.2$ & $37 \pm 4.8$ & $36 \pm 6.6$ & $34 \pm 5.2$ \\
\hline
\end{tabular}




\begin{tabular}{|c|c|c|c|c|c|c|c|}
\hline F. glandifera & Friend, 1911 & $F \_g l a$ & 0 & 0 & 0 & $1 \pm 0.4$ & 0 \\
\hline F. hegemon & (Vejdovský, 1878) & F_heg & 0 & $3 \pm 1.2$ & 0 & 0 & 0 \\
\hline F. isseli & Rota, 1994 & F_iss & $2 \pm 0.8$ & $7 \pm 2.9$ & $9 \pm 1.5$ & 0 & 0 \\
\hline F. lenta & Schmelz, 2003 & F_len & $3 \pm 1.2$ & $9 \pm 2.3$ & $3 \pm 1.2$ & $3 \pm 1.2$ & $2 \pm 0.2$ \\
\hline F. maculatiformis & Dózsa-Farkas, 1972 & $F_{-} m a f$ & 0 & $1 \pm 0.4$ & $4 \pm 1.6$ & $10 \pm 2.0$ & $5 \pm 1.2$ \\
\hline F. nemoralis & Nurminen, 1970 & F_nem & $17 \pm 3.2$ & $42 \pm 5.1$ & $36 \pm 5.2$ & $36 \pm 5.3$ & $24 \pm 3.0$ \\
\hline F. paroniana & Issel, 1904 & F_par & $4 \pm 1.0$ & $5 \pm 2.0$ & $11 \pm 2.9$ & $2 \pm 0.5$ & $1 \pm 0.4$ \\
\hline F. perrieri & (Vejdovský, 1878) & F_per & $2 \pm 0.5$ & 0 & $2 \pm 0.8$ & $11 \pm 3.0$ & 0 \\
\hline F. ratzeli & (Eisen, 1872) & $F_{-}$rat & 0 & $1 \pm 0.4$ & $10 \pm 2.7$ & 0 & $3 \pm 1.2$ \\
\hline F. regularis & Nielsen \& Christensen, 1959 & F_reg & 0 & 0 & 0 & 0 & 0 \\
\hline F. rendsinata & Dózsa-Farkas, 1972 & F_ren & $13 \pm 4.0$ & $1 \pm 0.4$ & 0 & $4 \pm 1.6$ & 0 \\
\hline F. semisetosa & Dózsa-Farkas, 1970 & F_sem & 0 & 0 & 0 & $4 \pm 1.2$ & $4 \pm 1.2$ \\
\hline F. sylvatica & Healy, 1979 & $F_{-}$syl & $11 \pm 2.2$ & $12 \pm 2.4$ & $5 \pm 1.2$ & $20 \pm 3.8$ & $9 \pm 2.0$ \\
\hline F. tubulosa & Dózsa-Farkas, 1972 & F_tub & $3 \pm 1.2$ & 0 & $1 \pm 0.4$ & $1 \pm 0.4$ & 0 \\
\hline F. waldenstroemi & Rota \& Healy, 1999 & F_wal & 0 & $2 \pm 0.8$ & $3 \pm 1.2$ & $4 \pm 1.2$ & $2 \pm 0.8$ \\
\hline Henlea nasuta & (Eisen, 1878) & H_nas & 0 & $3 \pm 1.2$ & $3 \pm 1.2$ & $11 \pm 3.6$ & $6 \pm 1.5$ \\
\hline H. perpusilla & Friend, 1911 & H_per & 0 & $3 \pm 1.2$ & 0 & $6 \pm 2.4$ & $3 \pm 1.2$ \\
\hline H. similis & Nielsen \& Christensen, 1959 & H_sim & $3 \pm 1.2$ & $3 \pm 1.2$ & 0 & $7 \pm 2.9$ & $6 \pm 1.7$ \\
\hline Marionina communis & Nielsen \& Christensen, 1959 & M_com & $3 \pm 1.2$ & 0 & $3 \pm 1.2$ & 0 & $9 \pm 3.7$ \\
\hline Achaeta juv. & & A juv & $13 \pm 3.5$ & $12 \pm 2.5$ & $19 \pm 2.0$ & $12 \pm 2.2$ & $4 \pm 1.6$ \\
\hline Enchytraeus juv. & & Ejuv & $51 \pm 6.1$ & $64 \pm 7.2$ & $18 \pm 4.4$ & $55 \pm 7.6$ & $74 \pm 5.5$ \\
\hline Fridericia juv. & & F juv & $32 \pm 2.3$ & $53 \pm 3.2$ & $38 \pm 3.6$ & $38 \pm 2.9$ & $32 \pm 3.9$ \\
\hline Henlea juv. & & H_juv & $1 \pm 0.4$ & $2 \pm 0.8$ & $1 \pm 0.4$ & $2 \pm 0.8$ & $2 \pm 0.8$ \\
\hline Marionina juv. & & M_juv & $1 \pm 0.4$ & 0 & 0 & 0 & 0 \\
\hline
\end{tabular}




\begin{tabular}{|c|c|c|c|c|c|c|c|}
\hline & & & & & 2015 & & \\
\hline & Jpectos & & C & CC & G & $P$ & $\mathrm{R}$ \\
\hline Achaeta danica & Nielsen \& Christensen, 1959 & A_dan & $8 \pm 2.8$ & $5 \pm 2.0$ & $2 \pm 0.8$ & $35 \pm 2.9$ & $4 \pm 1.2$ \\
\hline A. eiseni & Vejdovský, 1878 & A_eis & $16 \pm 2.4$ & $8 \pm 2.1$ & $8 \pm 3.3$ & $31 \pm 2.4$ & 0 \\
\hline A. pannonica & Graefe, 1989 & A_pan & $12 \pm 2.5$ & $7 \pm 2.0$ & $8 \pm 1.5$ & $6 \pm 2.0$ & $15 \pm 1.6$ \\
\hline $\begin{array}{l}\text { Buchholzia } \\
\text { appendiculata }\end{array}$ & (Buchholz, 1862) & B_app & $55 \pm 3.2$ & $32 \pm 4.4$ & $61 \pm 4.2$ & $26 \pm 7.0$ & 0 \\
\hline $\begin{array}{l}\text { Enchytraeus } \\
\text { buchholzi s.l. }\end{array}$ & Vejdovský, 1879 & E_buh & 0 & $21 \pm 3.1$ & $44 \pm 6.0$ & $34 \pm 2.2$ & $20 \pm 2.3$ \\
\hline E. bulbosus & Nielsen \& Christensen, 1963 & E_bul & $20 \pm 3.1$ & 0 & 0 & $3 \pm 0.5$ & 0 \\
\hline Enchytronia parva & Nielsen \& Christensen, 1959 & En_pa & $41 \pm 2.8$ & 0 & $5 \pm 2.0$ & $28 \pm 2.3$ & $2 \pm 0.8$ \\
\hline Fridericia alata & Nielsen \& Christensen, 1959 & F_ala & 0 & 0 & 0 & 0 & 0 \\
\hline F. cf. aurita & Issel, 1905 & F_aur & $7 \pm 1.2$ & 0 & 0 & $6 \pm 0.6$ & $1 \pm 0.4$ \\
\hline F. benti & Schmelz, 2002 & F_ben & 0 & 0 & 0 & $15 \pm 2.2$ & $5 \pm 1.6$ \\
\hline F. bisetosa & (Levinsen, 1884) & F_bis & $30 \pm 3.3$ & $2 \pm 0.5$ & 0 & $1 \pm 0.4$ & $5 \pm 0.8$ \\
\hline F. bulboides & Nielsen \& Christensen, 1959 & F_bul & $18 \pm 3.0$ & $1 \pm 0.4$ & 0 & 0 & 0 \\
\hline F. cf. conculcata & Dózsa-Farkas, 1986 & $F_{-} \mathrm{cul}$ & 0 & 0 & 0 & 0 & 0 \\
\hline F. connata & Bretscher, 1902 & F_con & $26 \pm 2.7$ & $27 \pm 5.6$ & $53 \pm 4.3$ & $28 \pm 3.3$ & $27 \pm 2.4$ \\
\hline F. dura & (Eisen, 1879) & F_dur & $1 \pm 0.4$ & $1 \pm 0.4$ & $10 \pm 1.2$ & 0 & $4 \pm 0.8$ \\
\hline F. galba & (Hoffmeister, 1843) & F_gal & $34 \pm 3.1$ & $4 \pm 1.6$ & $22 \pm 1.8$ & $32 \pm 4.0$ & $6 \pm 1.7$ \\
\hline F. glandifera & Friend, 1911 & F_gla & 0 & 0 & 0 & $1 \pm 0.4$ & 0 \\
\hline F. hegemon & (Vejdovský, 1878) & F_heg & $2 \pm 0.8$ & 0 & $3 \pm 0.8$ & $2 \pm 0.8$ & 0 \\
\hline F. isseli & Rota, 1994 & F_iss & $7 \pm 0.8$ & $1 \pm 0.4$ & $2 \pm 0.5$ & 0 & 0 \\
\hline F. lenta & Schmelz, 2003 & F_len & $1 \pm 0.4$ & $1 \pm 0.4$ & $6 \pm 0.9$ & $8 \pm 2.4$ & $6 \pm 2.4$ \\
\hline F. maculatiformis & Dózsa-Farkas, 1972 & $F_{-} m a f$ & $4 \pm 0.8$ & $17 \pm 1.7$ & $2 \pm 0.8$ & $1 \pm 0.4$ & $2 \pm 0.8$ \\
\hline F. nemoralis & Nurminen, 1970 & F_nem & $42 \pm 3.7$ & $21 \pm 3.1$ & $21 \pm 3.0$ & $45 \pm 5.9$ & $8 \pm 2.2$ \\
\hline F. paroniana & Issel, 1904 & F_par & $36 \pm 3.3$ & $3 \pm 1.2$ & $1 \pm 0.4$ & 0 & 0 \\
\hline
\end{tabular}




\begin{tabular}{|c|c|c|c|c|c|c|c|}
\hline F. perrieri & (Vejdovský, 1878) & F_per & $2 \pm 0.8$ & 0 & $25 \pm 1.7$ & $4 \pm 1.2$ & 0 \\
\hline F. ratzeli & (Eisen, 1872) & F_rat & 0 & 0 & $5 \pm 1.2$ & 0 & 0 \\
\hline F. regularis & Nielsen \& Christensen, 1959 & F_reg & 0 & 0 & 0 & 0 & 0 \\
\hline F. rendsinata & Dózsa-Farkas, 1972 & F_ren & 0 & $9 \pm 2.5$ & 0 & 0 & $11 \pm 3.3$ \\
\hline F. semisetosa & Dózsa-Farkas, 1970 & F_sem & $3 \pm 0.8$ & 0 & $2 \pm 0.5$ & 0 & $3 \pm 0.8$ \\
\hline F. sylvatica & Healy, 1979 & F_syl & $11 \pm 3.0$ & $33 \pm 3.6$ & $39 \pm 2.6$ & $16 \pm 2.0$ & $13 \pm 3.1$ \\
\hline F. tubulosa & Dózsa-Farkas, 1972 & F_tub & 0 & 0 & $4 \pm 1.6$ & 0 & 0 \\
\hline F. waldenstroemi & Rota \& Healy, 1999 & F_wal & $15 \pm 1.5$ & 0 & $7 \pm 1.2$ & 0 & $3 \pm 1.2$ \\
\hline Henlea nasuta & (Eisen, 1878) & H_nas & 0 & $8 \pm 1.9$ & $3 \pm 1.2$ & $4 \pm 1.6$ & 0 \\
\hline H. perpusilla & Friend, 1911 & H_per & 0 & 0 & $17 \pm 2.3$ & $8 \pm 2.4$ & $2 \pm 0.8$ \\
\hline H. similis & Nielsen \& Christensen, 1959 & H_sim & 0 & $2 \pm 0.8$ & $2 \pm 0.8$ & $1 \pm 0.4$ & $2 \pm 0.5$ \\
\hline Marionina communis & Nielsen \& Christensen, 1959 & M_com & $3 \pm 1.2$ & $2 \pm 0.8$ & $5 \pm 2.0$ & 0 & $1 \pm 0.4$ \\
\hline Achaeta juv. & & A juv & $1 \pm 0.4$ & $5 \pm 2.0$ & 0 & $18 \pm 4.8$ & $18 \pm 2.3$ \\
\hline Enchytraeus juv. & & Ejuv & $76 \pm 7.4$ & $40 \pm 5.8$ & $68 \pm 10.0$ & $55 \pm 5.6$ & $27 \pm 2.2$ \\
\hline Fridericia juv. & & F juv & $47 \pm 5.0$ & $57 \pm 5.0$ & $67 \pm 8.5$ & $66 \pm 4.8$ & $46 \pm 3.2$ \\
\hline Henlea juv. & & H_juv & 0 & 0 & $2 \pm 0.5$ & 0 & 0 \\
\hline Marionina juv. & & M_juv & 0 & 0 & 0 & 0 & 0 \\
\hline
\end{tabular}




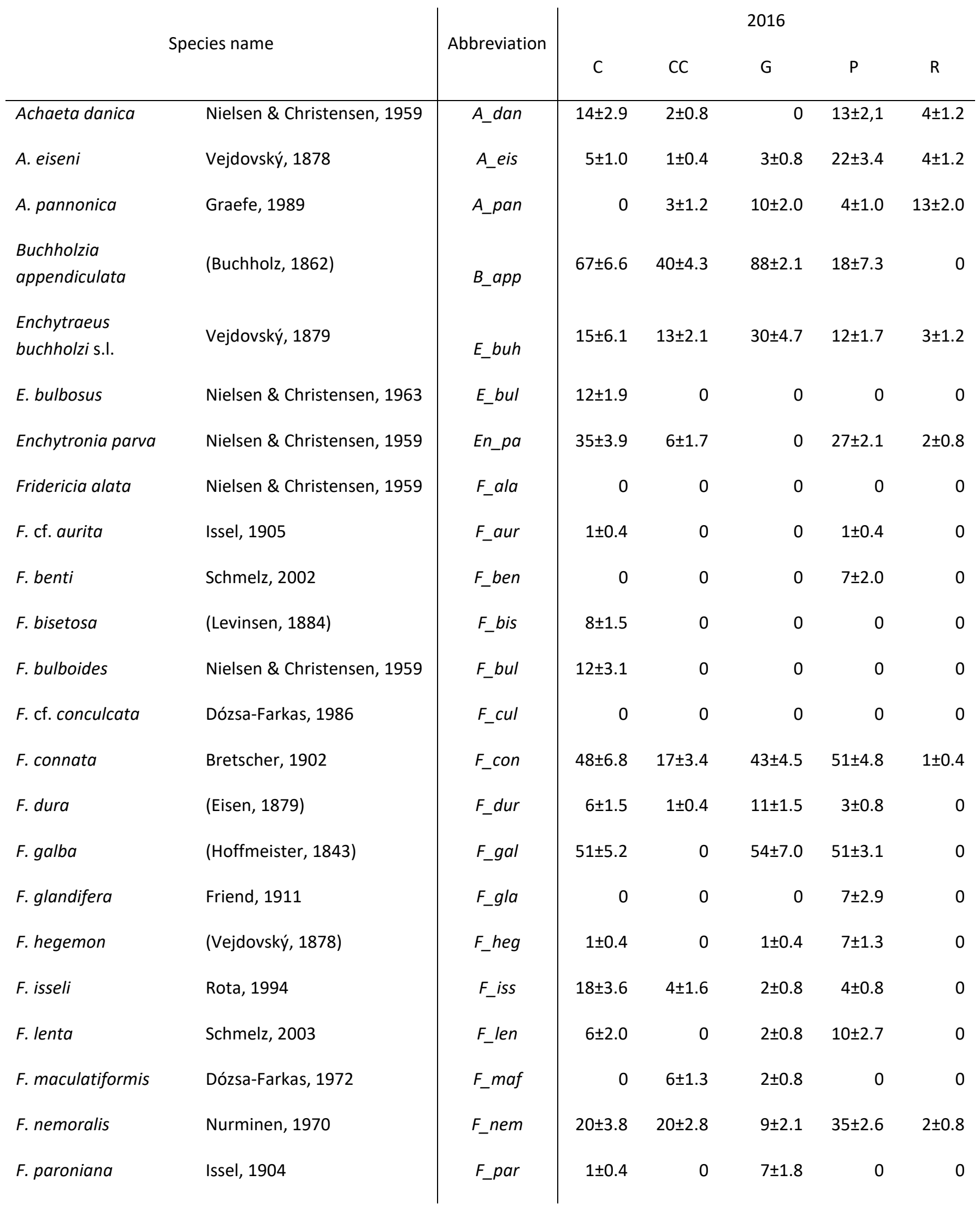




\begin{tabular}{|c|c|c|c|c|c|c|c|}
\hline F. perrieri & (Vejdovský, 1878) & F_per & $14 \pm 4.8$ & 0 & $5 \pm 1.2$ & $8 \pm 2.8$ & 0 \\
\hline F. ratzeli & (Eisen, 1872) & $F_{-}$rat & $4 \pm 1.2$ & $4 \pm 1.6$ & $7 \pm 1.6$ & $1 \pm 0.4$ & 0 \\
\hline F. regularis & Nielsen \& Christensen, 1959 & F_reg & 0 & 0 & $15 \pm 3.2$ & $6 \pm 2.0$ & 0 \\
\hline F. rendsinata & Dózsa-Farkas, 1972 & F_ren & $2 \pm 0.8$ & $7 \pm 1.8$ & 0 & $6 \pm 2.4$ & $1 \pm 0.4$ \\
\hline F. semisetosa & Dózsa-Farkas, 1970 & F_sem & $3 \pm 0.8$ & 0 & 0 & 0 & 0 \\
\hline F. sylvatica & Healy, 1979 & F_syl & $16 \pm 3.7$ & $3 \pm 0.5$ & $10 \pm 1.6$ & $23 \pm 2.1$ & $1 \pm 0.4$ \\
\hline F. tubulosa & Dózsa-Farkas, 1972 & $F_{-} t u b$ & $1 \pm 0.4$ & $3 \pm 1.2$ & $6 \pm 2.4$ & $13 \pm 2.7$ & $1 \pm 0.4$ \\
\hline F. waldenstroemi & Rota \& Healy, 1999 & $F_{-} w a l$ & $7 \pm 1.9$ & 0 & $8 \pm 1.5$ & $1 \pm 0.4$ & 0 \\
\hline Henlea nasuta & (Eisen, 1878) & H_nas & $4 \pm 1.6$ & $32 \pm 6.3$ & $28 \pm 10.0$ & $8 \pm 1.5$ & 0 \\
\hline H. perpusilla & Friend, 1911 & H_per & 0 & $7 \pm 1.8$ & $50 \pm 5.8$ & $10 \pm 2.7$ & 0 \\
\hline H. similis & Nielsen \& Christensen, 1959 & H_sim & 0 & $14 \pm 4.4$ & $10 \pm 2.3$ & $6 \pm 2.4$ & 0 \\
\hline Marionina communis & Nielsen \& Christensen, 1959 & M_com & $9 \pm 3.2$ & $21 \pm 3.0$ & $19 \pm 4.7$ & $7 \pm 1.8$ & 0 \\
\hline Achaeta juv. & & A juv & $11 \pm 2.2$ & 0 & $1 \pm 0.4$ & $9 \pm 2.8$ & $31 \pm 1.9$ \\
\hline Enchytraeus juv. & & Ejuv & $28 \pm 4.1$ & $14 \pm 3.0$ & $30 \pm 4.6$ & $44 \pm 5.6$ & $13 \pm 2.6$ \\
\hline Fridericia juv. & & F_juv & $53 \pm 5.7$ & $52 \pm 5.9$ & $91 \pm 8.0$ & $81 \pm 6.4$ & $18 \pm 2.1$ \\
\hline Henlea juv. & & H_juv & 0 & 0 & 0 & 0 & 0 \\
\hline Marionina juv. & & M_juv & $7 \pm 2.9$ & 0 & 0 & 0 & 0 \\
\hline
\end{tabular}



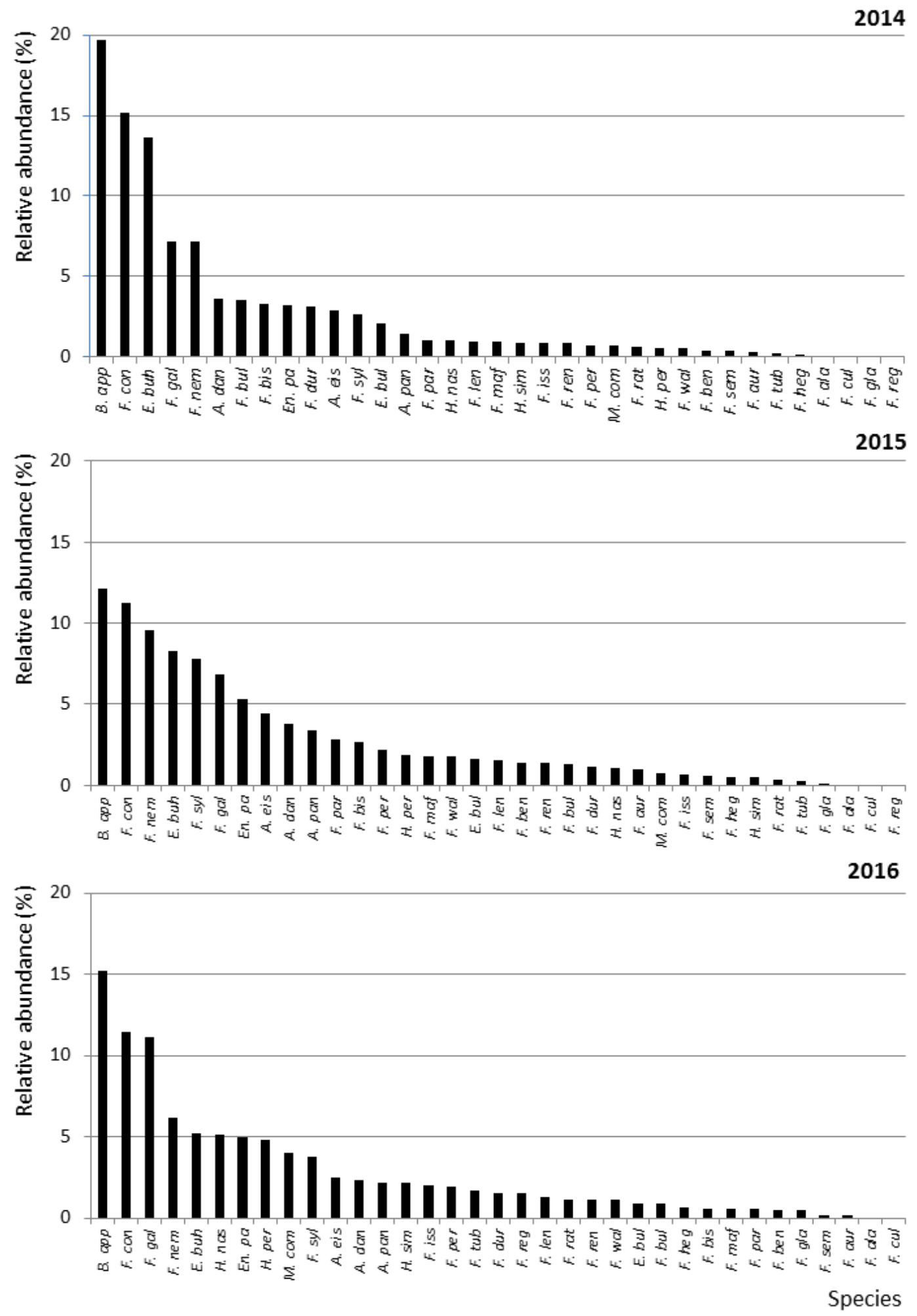
Figure S1. Distribution of relative abundance (\%) of the found species in 2014, 2015 and 2016. Species name abbreviations are shown in Table $\mathrm{S} 2$. 